\title{
Body Dimensions for Apparel
}

\section{Yung-Tsun Tina Lee}

U.S. DEPARTMENT OF COMMERCE Technology Administration National Institute of Standards and Technology Manufacturing Engineering Laboratory Factory Automation Systems Division Gaithersburg, MD 20899

$-Q C$

100

.056 



\section{NISTIR 5411}

\section{Body Dimensions for Apparel}

\section{Yung-Tsun Tina Lee}

U.S. DEPARTMENT OF COMMERCE Technology Administration National Institute of Standards and Technology

Manufacturing Engineering Laboratory Factory Automation Systems Division Gaithersburg, MD 20899

April 1994

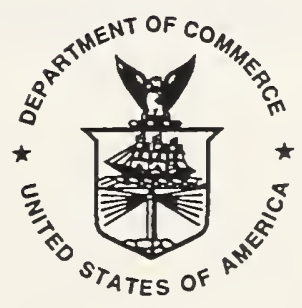

U.S. DEPARTMENT OF COMMERCE Ronald H. Brown, Secretary

TECHNOLOGY ADMINISTRATION Mary $L$ Good, Under Socretary for Technology

NATIONAL INSTITUTE OF STANDARDS AND TECHNOLOGY

Arat Prabhakar, Director 


\section{DISCLAIMER}

Certain commercial equipment, instruments, or materials are identified in this report in order to facilitate understanding. Such identification does not imply recommendation or endorsement by the National Institute of Standards and Technology, nor does it imply that the materials or equipment identified are necessarily the best available for the purpose. 


\title{
Body Dimensions for Apparel
}

\author{
Y. Tina Lee \\ Factory Automation Systems Division \\ Manufacturing Engineering Laboratory \\ National Institute of Standards and Technology \\ Gaithersburg, MD 20899
}

\begin{abstract}
Anthropometric data and apparel sizing is an important component of apparel quality. Apparel can not be top quality unless it fits the potential wearers satisfactorily. In the United States, current sizing standards rely on body measurement data that were gathered by the U.S. Department of Agriculture during the late 1930's. Apparel must fit today's population. Except for the study by the American Society for Testing and Materials to improve sizing for women over age 55, there has been no comprehensive anthropometric study of today's diverse population undertaken in the United States. Related issues such as definitions of body dimensions, body type classifications, measurement techniques, target population groups, and database management methods for the collection of body measurements all are important topics for apparel researchers.

This report represents a compilation of body dimensions that are used in the manufacturing and fitting of apparel. It is the result of a comparison of five body measurements reports, including documentations of national and international apparel sizing standards. The information in this report will provide the basis for the development of the information model of made-to-measure pattern making. It will also contribute to the conducting of future body measurements surveys and the development of new or improved sizing standards for apparel.
\end{abstract}

\section{KEY WORDS}

anthropometry; apparel; APDES; body dimensions; body measurements; fit; patterns; sizing 


\section{INTRODUCTION}

The apparel industry has used computer systems to automate many of its manufacturing processes. However, the manufacturing innovations often stand alone as "islands of automation." Integrating the separate automated processes could greatly improve the effectiveness of the entire enterprise. In recent years, the National Institute of Standards and Technology (NIST), under the sponsorship of the Defense Logistics Agency (DLA), has been developing the apparel product data exchange standard (APDES) [LEE1]. The goal of the APDES project is to develop a comprehensive specification for sharing apparel product data among all stages of the product life cycle. We, the APDES project members at NIST, have determined a set of manufacturing data interfaces that could be standardized for the effective integration of the information systems required to operate an apparel manufacturing enterprise [MONC]. We have also developed an information model for ready-to-wear pattern making, which is one of the manufacturing data interfaces being identified [LEE2].

We are currently developing an information model of made-to-measure pattern making and have conducted a literature survey on made-to-measure technology. As a result of the survey, a bibliography on apparel sizing and related issues has been generated for the quick use of apparel researchers [LEE3]. We are now working on a task to determine and organize the body dimensions necessary for manufacturing and fitting garments. The organized body dimensions can then be modelled and exchanged in an efficient manner with the apparel enterprise processes that need them.

One of the critical problems that impact the future development of made-to-measure quality garments is the need for reliable and accurate anthropometric data. Many designers, manufacturers, retailers, and customers are also concerned that the current apparel sizing standards do not describe the body configurations of today's population. The apparel industry needs consistent and accurate apparel sizing standards that reflect body measurements of today's population in order to increase the quality of ready-to-wear garments.

The purpose of this report is to present body dimensions that are needed for the fit and manufacture of garments and patterns. The body dimensions will provide the basis for the development of the information model of made-to-measure pattern making. It also provides a suggested list of data requirements for the collection of body measurements. The next section, Methodology, describes the process of compiling body dimensions. The Entries of Body Dimensions Table section lists types of information included in the Body Dimensions Table. The Table itself is shown in Appendix B. Appendix A is a compilation of principal body landmarks that are used in the definitions of Body Dimensions Table. The Summary section contains concluding remarks.

\section{METHODOLOGY}

There exists a wealth of anthropometric data collection, such as Anthropometry of Women of $U$. $S$. Army [CHUR], Anthropometry of Air Force Women [CLAU], the National Aeronautics and Space Administration's Anthropometry for Designers [MCCO], the Department of Agriculture's 
Body Measurements for Garment and Pattern Construction [OBR], etc. These anthropometric data were taken from different sources which used different body dimensions, body measurement methods, body referencing systems on different target population for different applications. For example, the Anthropometry for Designer was tailored to meet the needs of engineers engaged in the design of equipment, habitability areas, workspace layouts, life-support hardware, and clothing for the NASA (National Aeronautics and Space Administration) Space Shuttle/Spacelab program, and all anthropometric data were collected in the weightless environment. However, the Anthropometry of Women of the U. S. Army was generated during the winter of 1976-1977 to satisfy the need by the U. S. Army for up-to-date data on the body sizes and strength capabilities of Army women.

This article is aimed at the study of body measurements for apparel and pattern making only. Thus, five reports, [NBS], [NBS-m], [ISO], [ASTM], and [MD] (refer to the References section), were selected as references for this study from the bibliography that was generated previously [LEE3]. The approach of the study for this report is to compile body dimensions that will provide a complete coverage of those in the above five references. Definitions of all body dimensions in the references have been examined and compared. The comparison result is then summarized in a table that lists a set of body dimensions needed in the manufacturing and fitting of apparel. Body dimensions presented in different references with a common definition are grouped as one body dimension. A brief summary of each reference is described as follows.

[NBS] is a report on Body Measurements for the Sizing of Women's Patterns and Apparel. It is a voluntary product standard developed by the National Bureau of Standards (NBS). The standard covers standard size classifications, size designations, and body measurements to aid in the consistency of sizing of women's apparel. It also covers applications of the sizing system, definitions and methods of measurement, and recommended methods for identifying products that are sized in accordance with this standard.

[NBS-m] is a report on Body Measurements for the Sizing of Apparel for Men (Student). It is another NBS voluntary apparel sizing standard that covers same information as in the [NBS], but is aimed at young men or students.

[ISO] is a report on Garment Construction and Anthropometric Surveys - Body Dimensions. It is an international standard developed by the International Organization for Standardization. The standard defines the location of body dimensions for anthropometric surveys and for the preparation of garment patterns as well as garment stands. It also specifies a standard procedure for measuring the body.

[ASTM] is a report on Development of Body Measurement Tables for Women 55 and Older and the Relationship to Ready-to-Wear Garment Size. It provides the first set of specific body measurements of women 55 years and older. The study was performed by the ASTM (American Society for Testing and Materials) Institute for Standards Research. The report also identifies key body dimensions that are related to garment fitting problems for women aged 55 and over.

$[\mathrm{MD}]$ is a report on Measurement Specification Document. It provides information of mens' 
and womens' measurement specifications for two types of applications: interface by human user and interface by computer. The work was performed by the Microdynamics Inc. for supporting the Textile/Clothing Technology Corporation's made-to-measure technology research project. [MD] includes two separate documents: women's edition and mens' edition. Sixty-six dimensions are defined in the women's edition, while fifty-nine dimensions are in the men's edition. There are fifty-eight dimensions in common between men's and women's. Thus, the women's edition is used as the primary reference in this report.

\section{ENTRIES OF BODY DIMENSIONS TABLE}

Two appendices, Appendix A and Appendix B, are included in this report. Appendix A is a glossary of body landmarks used in the definitions of body dimensions. The Standard Terminology Relating to Body Dimensions for Apparel Sizing section in the "1992 Annual Book of ASTM Standards" was the main reference for developing this glossary [ASTM-d]. Appendix B presents a table containing all dimensions of the human body that are used in making patterns and garments based on the five reports mentioned above. All measurements are made with the subject standing upright unless otherwise specified. A total of ninety-one dimensions (items) are included in the table. Each dimension in the table is composed of five fields: numeric identification, dimension name, definition, category, and the references which include the dimension. The following provides a brief description of each field.

"Identification" defines an identification number for the body dimension.

"Name" gives a name for the body dimension. Each name is specified by a string of characters.

"Definition" provides a description of body locations and process for taking body measurement. Definitions are summarized from the five referenced reports.

"Category" gives a category for the body dimension. Five categories (girth, vertical, length, angle, and weight) are included in the table. "Girth" is a horizontal and circular measurement of the body. "Vertical" is a measure of the vertical distance for the required section of the body. "Length" is a measure of the distance between two or more measurement points. "Angle" is an angle of inclination measurement. "Weight" is a measure of the heaviness of the subject.

"References" lists a set of references by abbreviation which include the dimension and the location of the definition (by paragraph number) in each reference.

\section{SUMMARY}

This report presents a preliminary set of body dimensions that are necessary in the manufacturing and fitting of apparel. The information of these body dimensions will be the basis for the development of the information model of made-to-measure pattern making. Requirements of body 
measurements for different groups of people are somewhat varied. (Groups of people may depend on ages, genders, ethnic origin, etc.) Further study may be necessary to determine body

dimensions requirements for the specific groups. For completeness, additions and modifications to the preliminary set of body dimensions will be needed. The author expects that the information in this report will contribute to future body measurements surveys as well as the development of new or improved sizing standards.

\section{REFERENCES}

[ASTM] Institute for Standards Research, "Development of Body Measurement Tables for Women 55 and Older and the Relationship to Ready-to-Wear Garment Size," ISR 06, PCN: 3300006-18, ASTM Institute for Standards Research, Philadelphia, PA, 1993.

[ASTM-d] ASTM Committee D-13, “1992 Annual Book of ASTM Standards," Volume 07.02, ASTM, Philadelphia, PA, 1992.

[CHUR] Churchill, E., Churchill, T., McConville, J. T., and White R. M., "Anthropometry of Women of the U.S. Army - 1977 Report No. 2 - The Basic Univariate Statistics," U.S. Army Natick Technical Report (Natick/TR-77/024), U.S. Army Natick Research and Development Command, Natick, MA, June 1977.

[CLAU] Clauser, C. E., Tucker, P. E., McConville J. T., Churchill, E., Laubach, L. L., and Reardon J. A., "Anthropometry of Air Force Women," Aerospace Medical Research Laboratory Technical Report (AMRL-TR-70-5), Wright-Patterson Air Force Base, OH, April 1972.

[ISO] International Organization for Standardization, "Garment Construction and Anthropometric Surveys - Body Dimensions," ISO 8559, International Organization for Standardization, Geneva, Switzerland, 1989.

[LEE1] Lee, Y. T., "Apparel Product Data Exchange Standard," Proceedings of the Third Annual Apparel Research Conference: Implementing Advanced Technology, Atlanta, GA, February 1992.

[LEE2] Lee, Y. T., and Moncarz, H.T., "A Prototype Application Protocol for Ready-toWear Pattern Making," NISTIR 5115, National Institute of Standards and Technology, Gaithersburg, MD, January 1993.

[LEE3] Lee, Y. T., "A Bibliography on Apparel Sizing and Related Issues," NISTIR 5365, National Institute of Standards and Technology, Gaithersburg, MD, February 1994.

[MCCO] McConville, J. T., "Anthropometric Source Book Volume I: Anthropometry for Designers," NASA Reference Publication 1024, National Aeronautics and Space Administration, Scientific and Technical Information Office, 1978. 


\section{Page 6}

[MD] Microdynamics PAS Committee, "Measurement Specification Document, Women's Edition and Mens' Edition," Microdynamics Inc., Dallas, TX, 1992.

[MONC] Moncarz, H. T., and Lee, Y. T., "Report on Scoping the Apparel Manufacturing Enterprise," Vol. 5, No. 3/4, International Journal of Clothing Science and Technology, MCB University Press Limited, Bradford, UK, 1993.

[NBS] National Bureau of Standards, "Body Measurements for the Sizing of Women's Patterns and Apparel," NBS Voluntary Product Standard PS 42-70, United States Department of Commerce/National Bureau of Standards, Gaithersburg, MD, 1971.

[NBS-m] National Bureau of Standards, "Body Measurements for the Sizing of Apparel for Men (Student)," NBS Voluntary Product Standard PS 45-71, United States Department of Commerce/National Bureau of Standards, Gaithersburg, MD, 1972.

[OBR] Department of Agriculture, "Women's Measurements for Garment and Pattern Construction," Miscellaneous Publication No. 454, Government Printing Office, Washington D.C., 1941 . 
Page 7

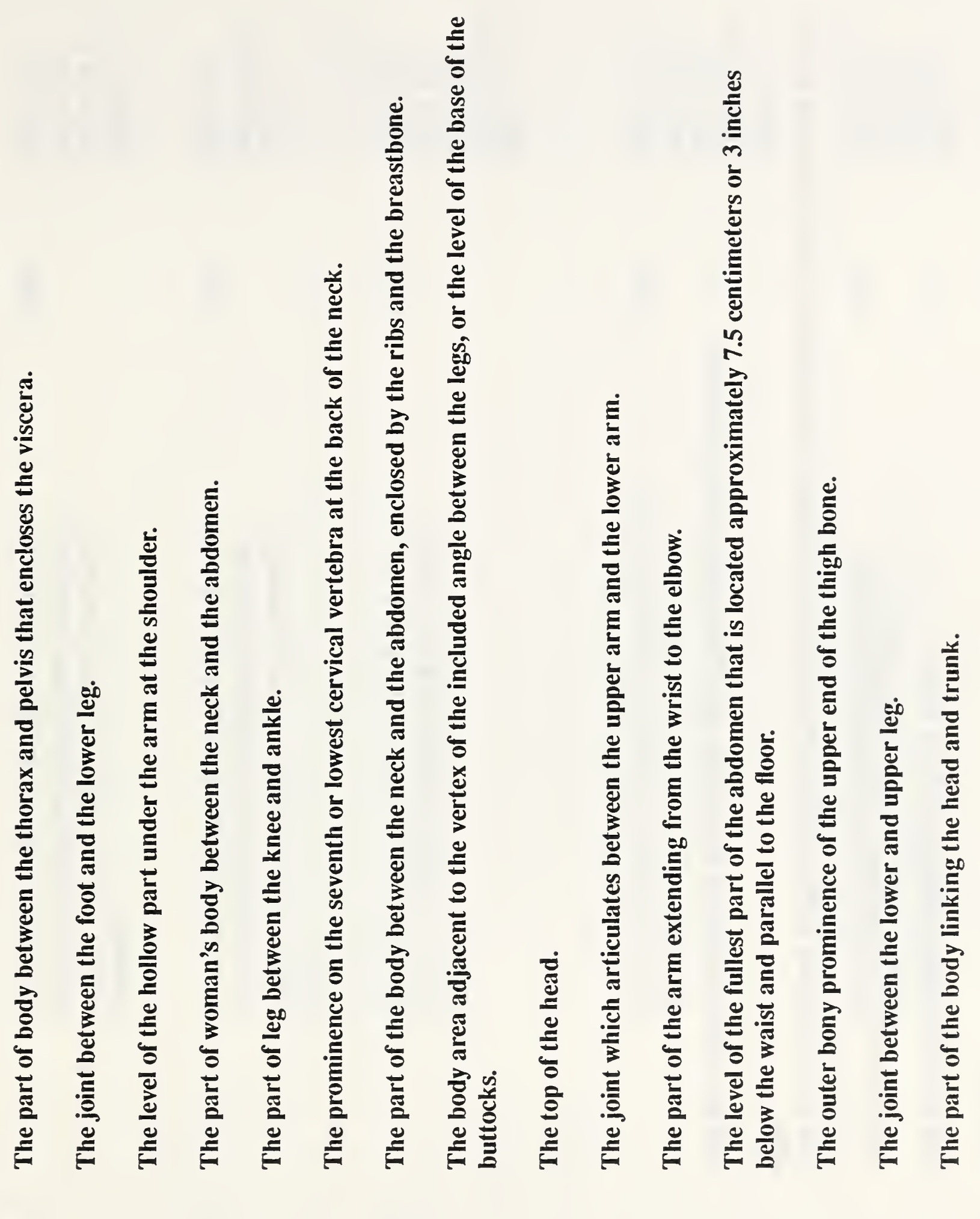

. 
Page 8

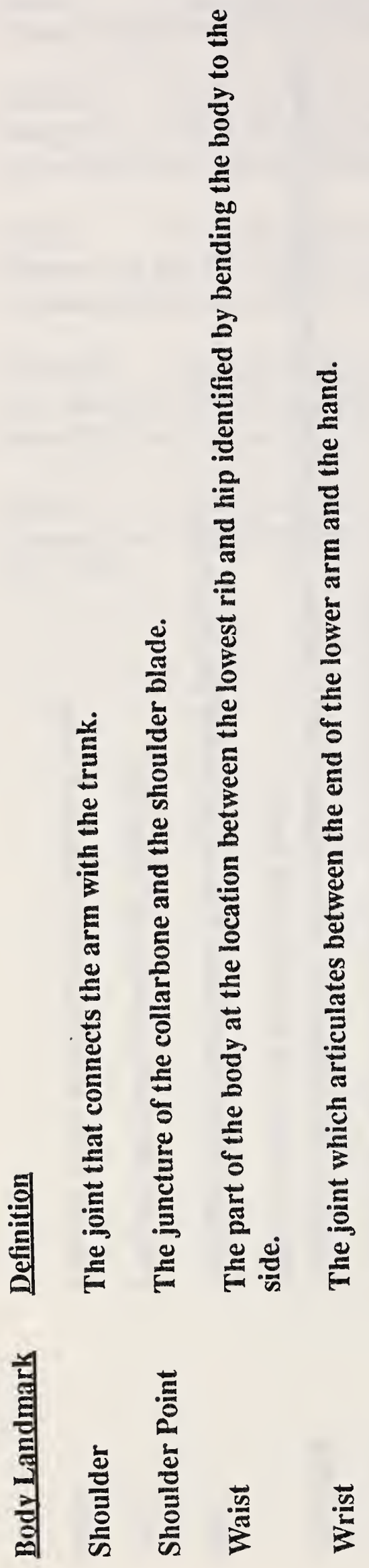



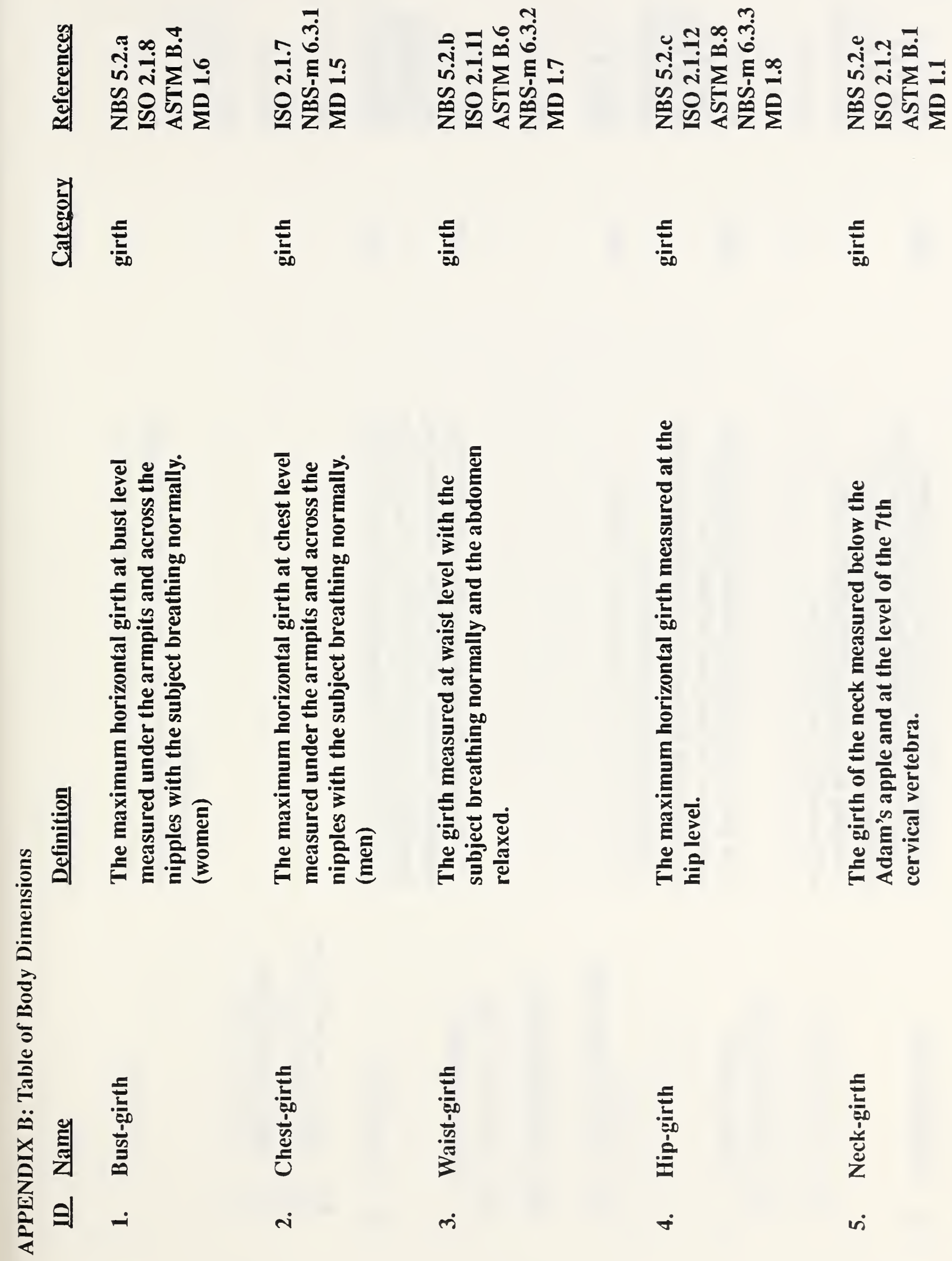


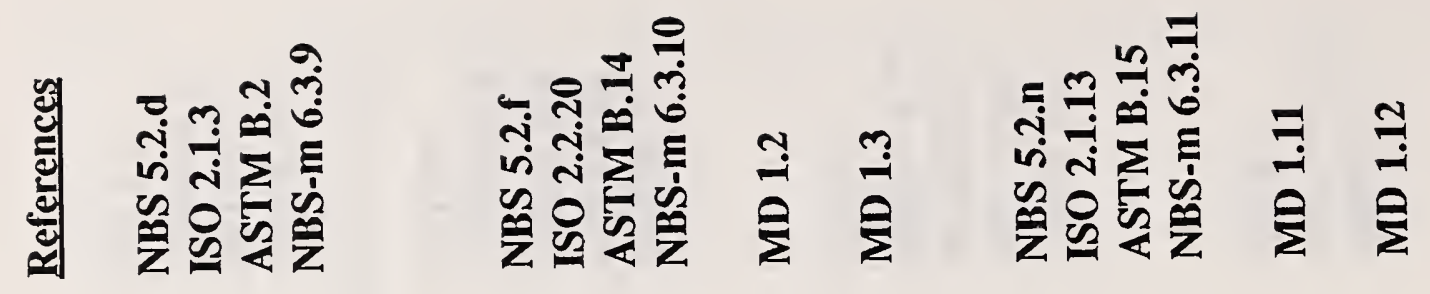

基言

言

言
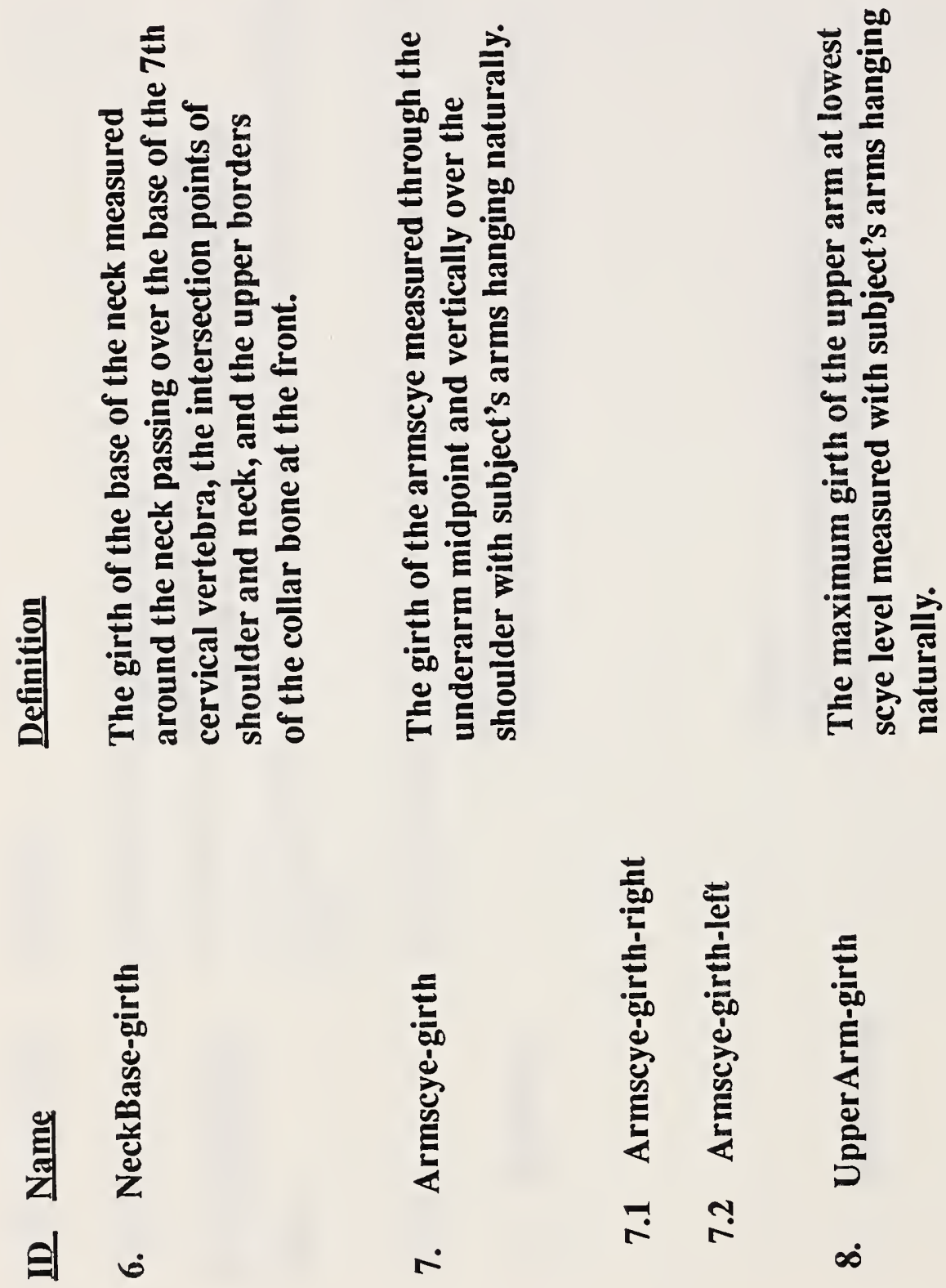

हై

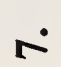

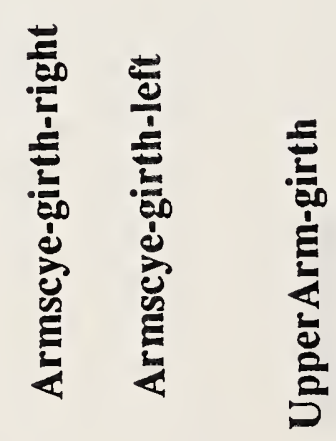

푸ำ

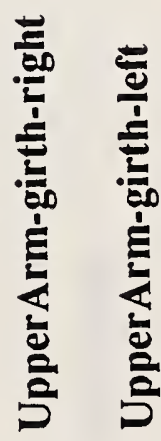

$\vec{\infty}$ 


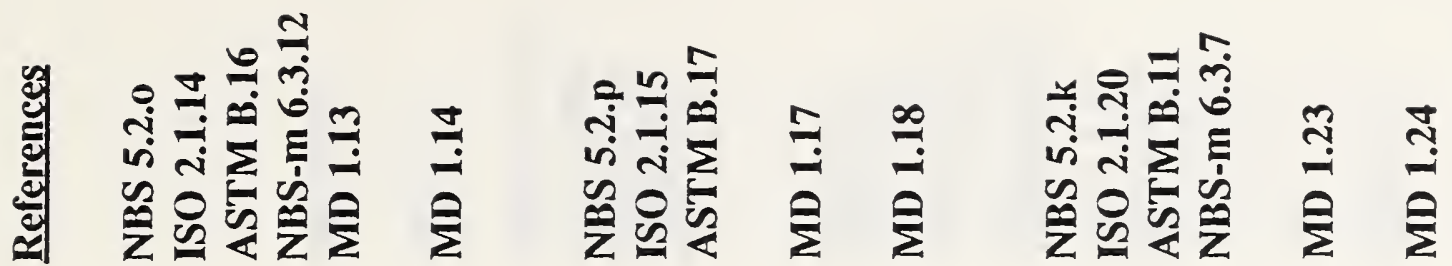

章

言

言

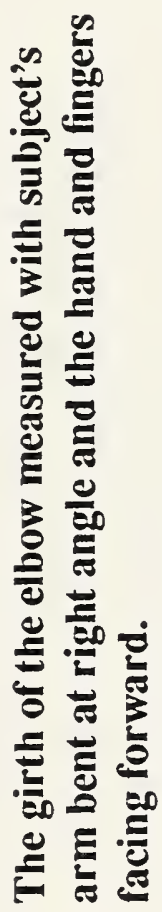

हอ

齿

产

टे

突

E

के

气

을

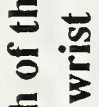

畜总总

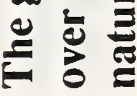

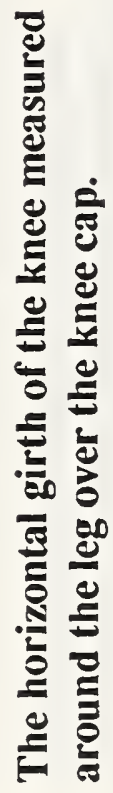

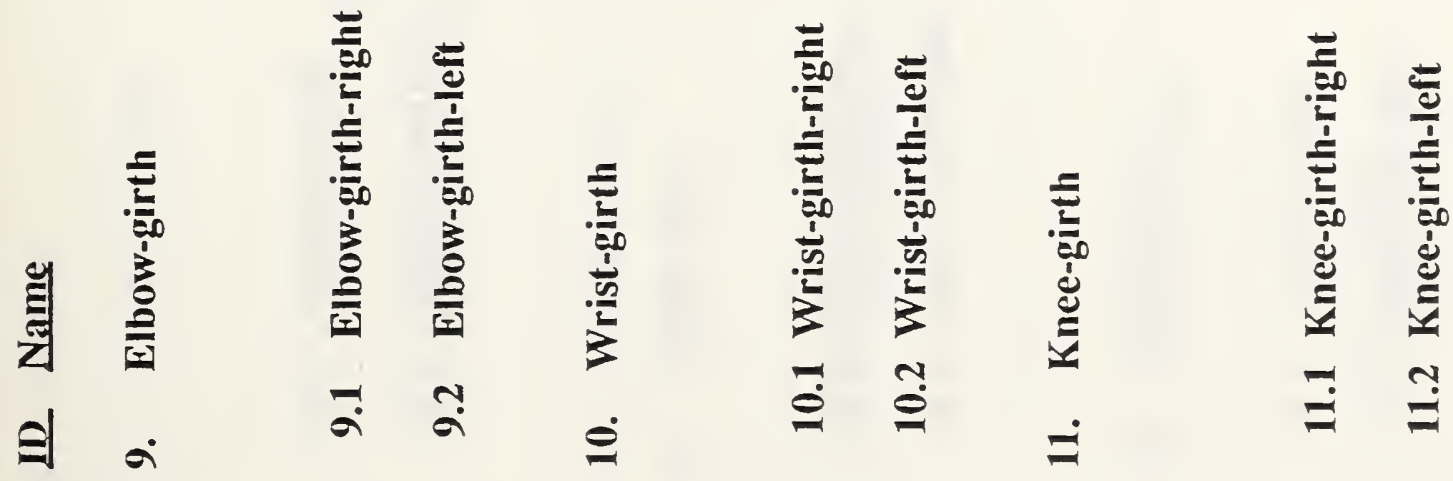




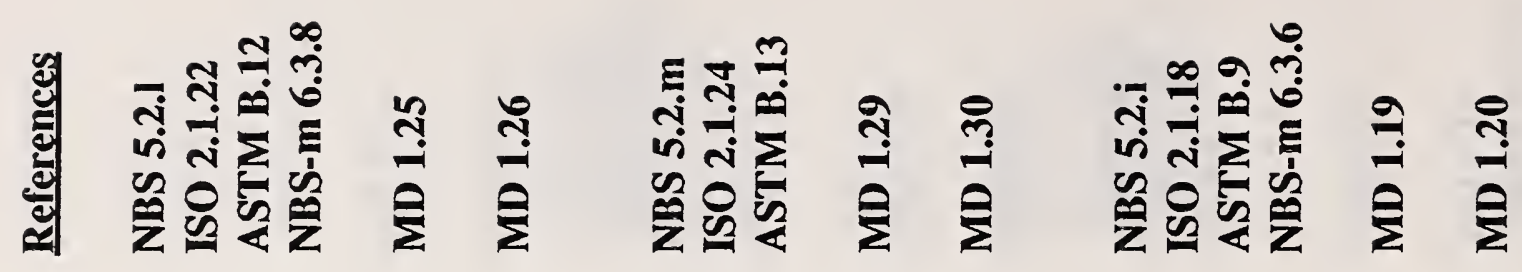
昜

言

言
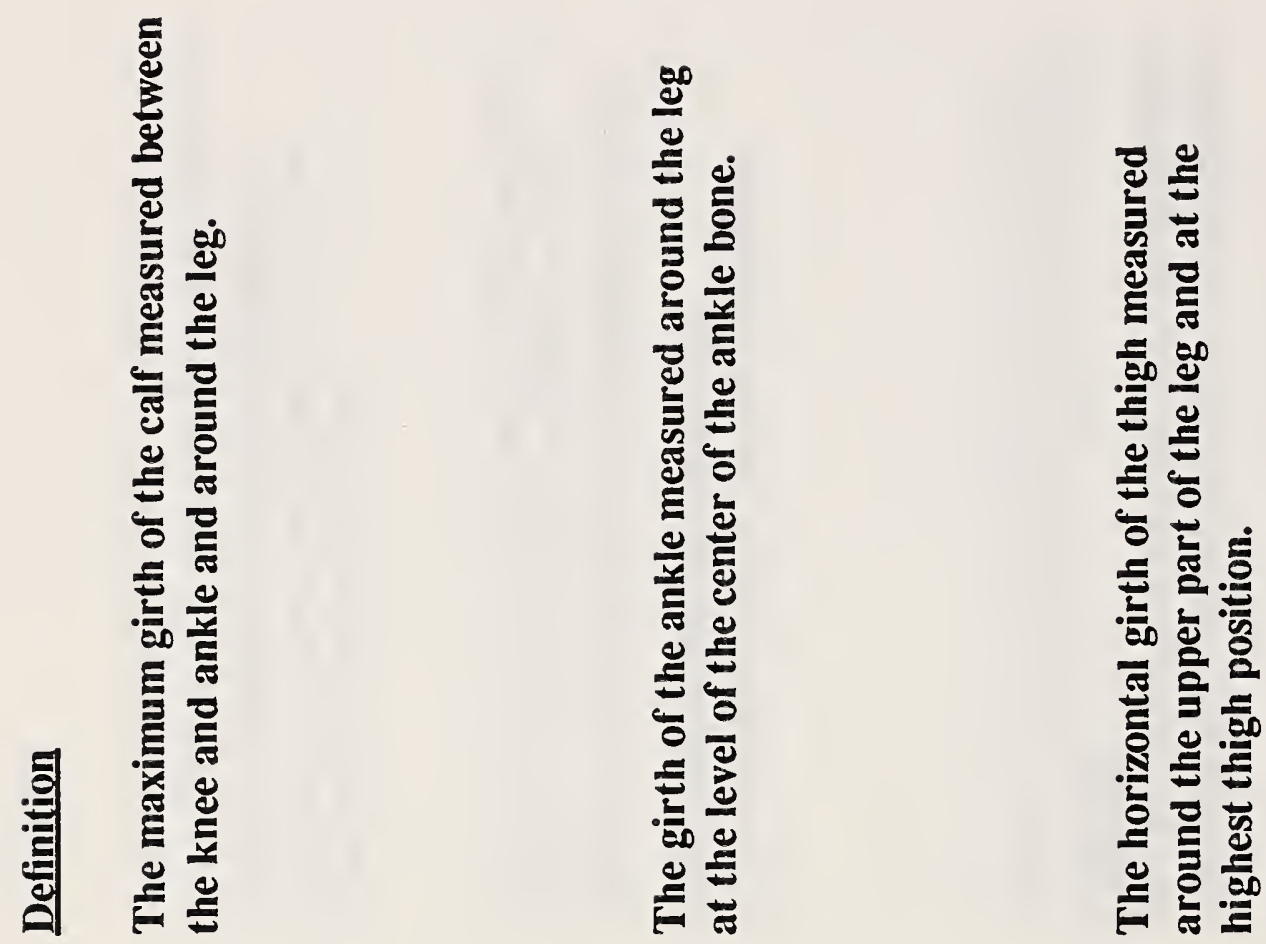

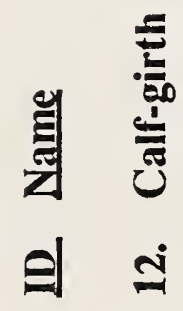
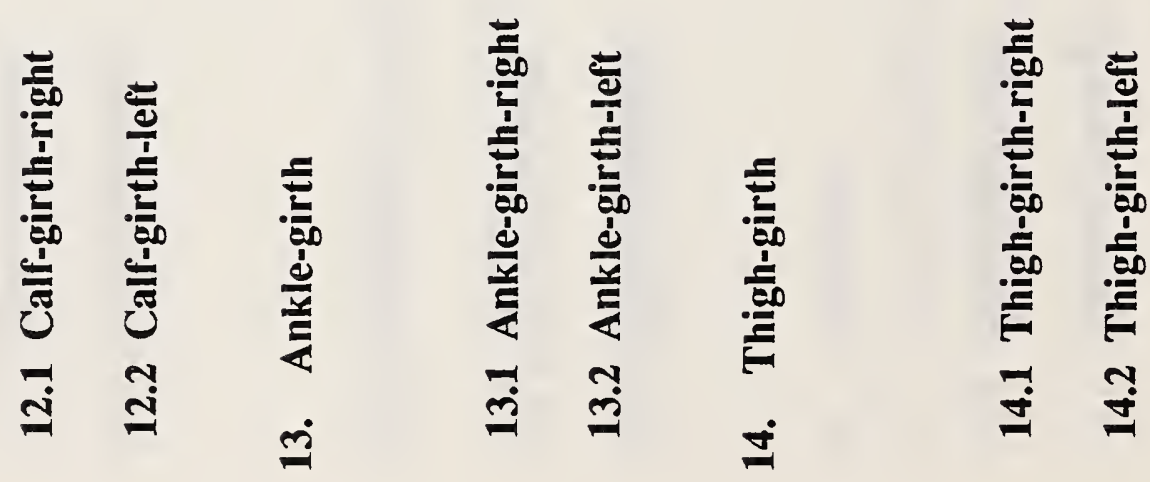


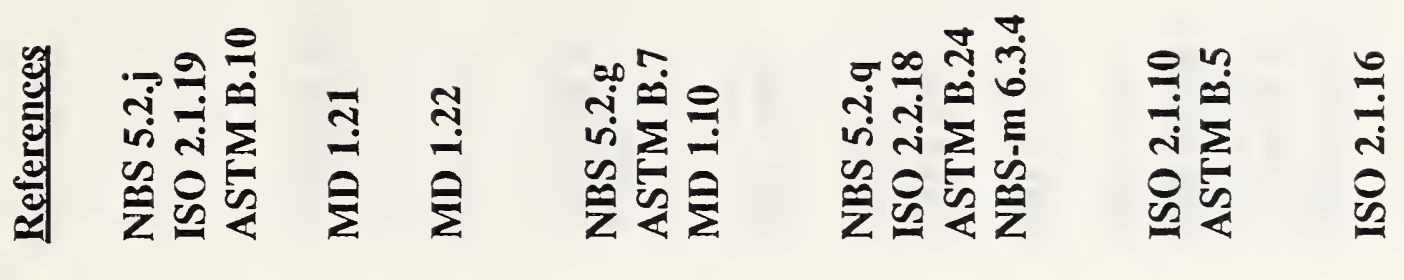

亲

言

嬉

를

돌
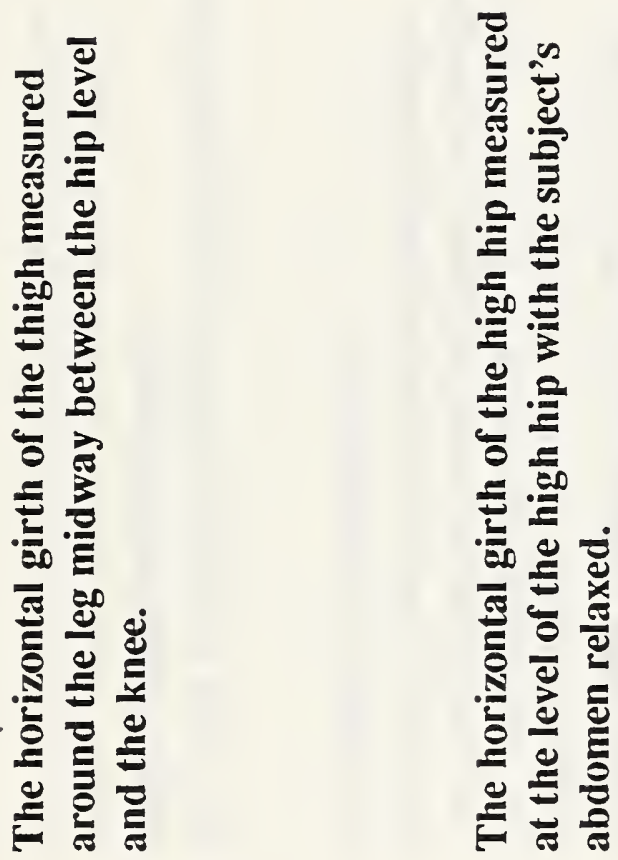

๖ัญ

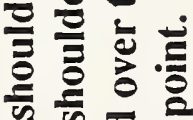

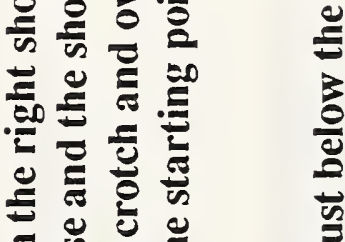

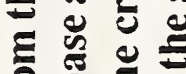

은 3

¿

帘至

㝳

르
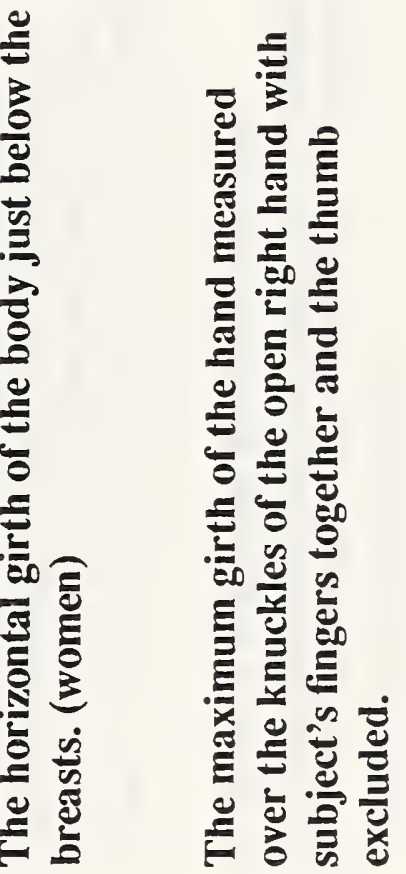

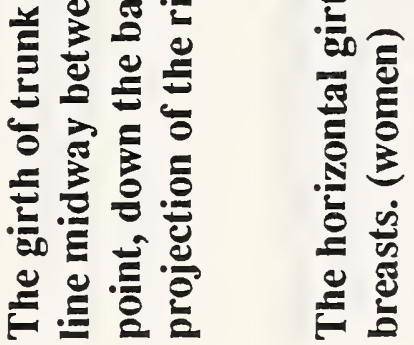

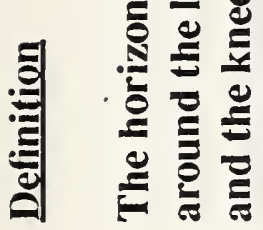

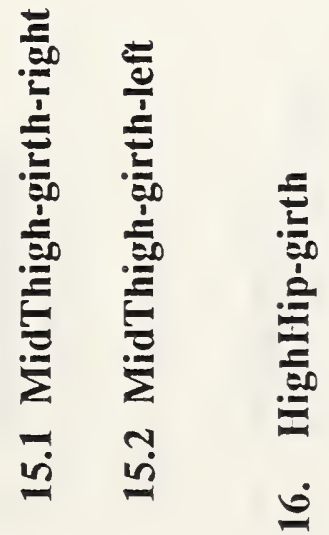

赵

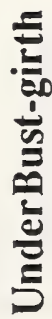

氮

요

$\underline{-}$

N

$\infty$

20 
Page 14

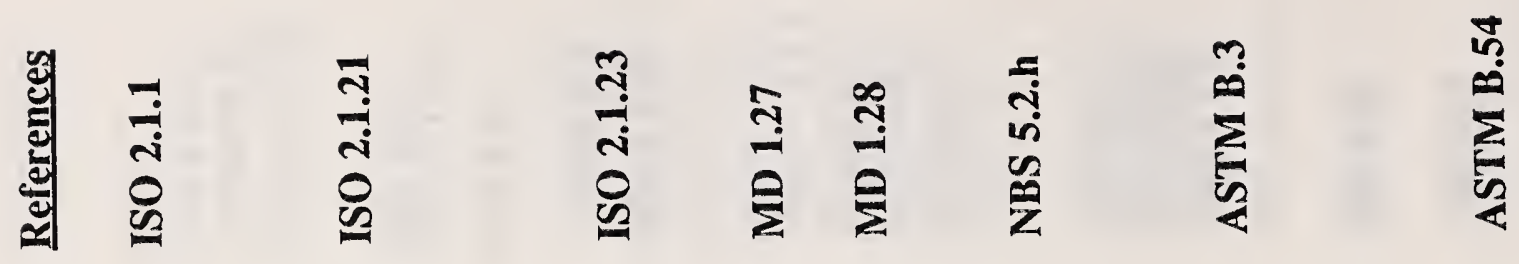

基言言言言言言言

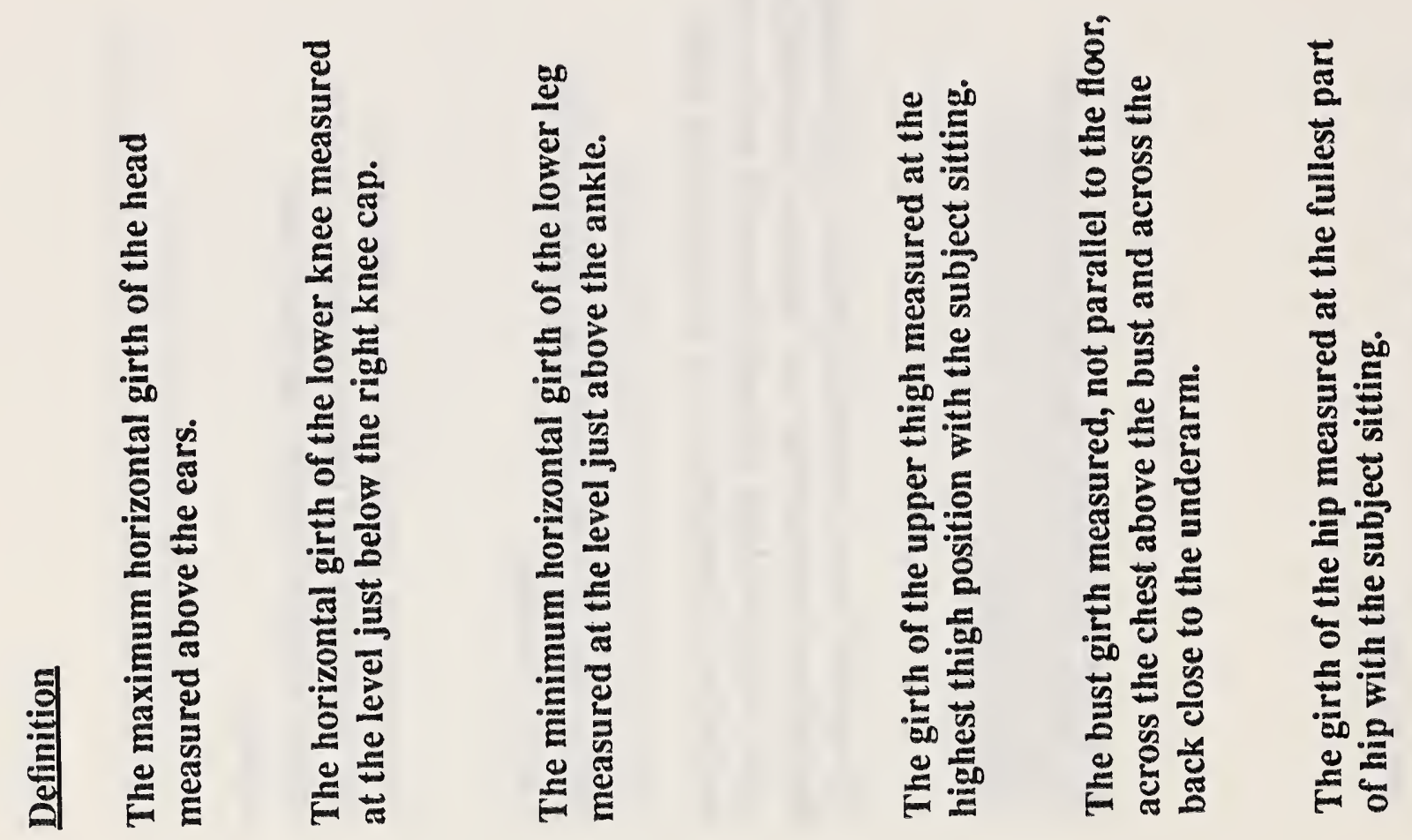

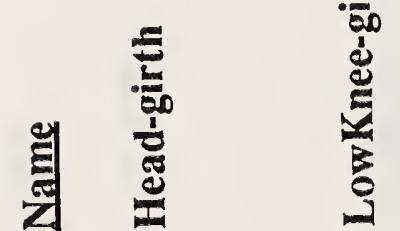

이 ते

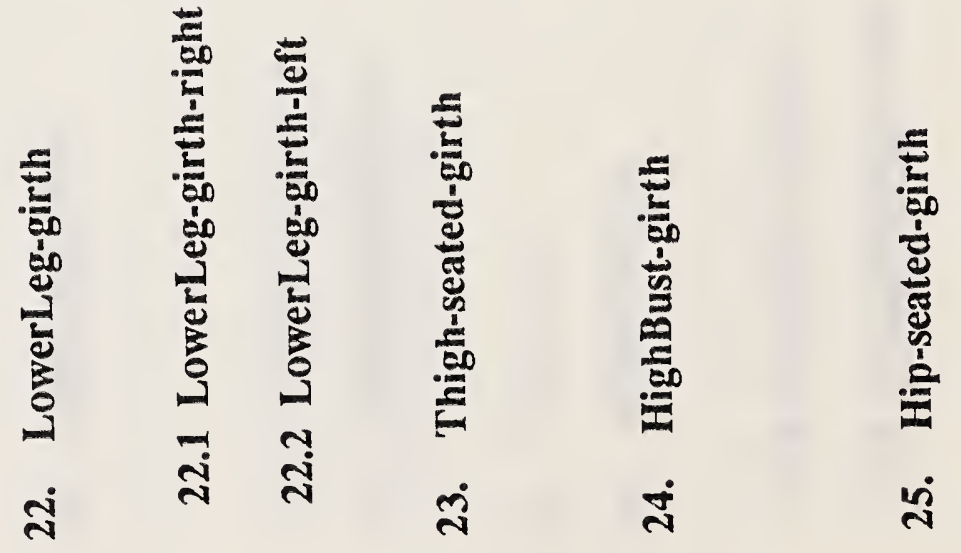




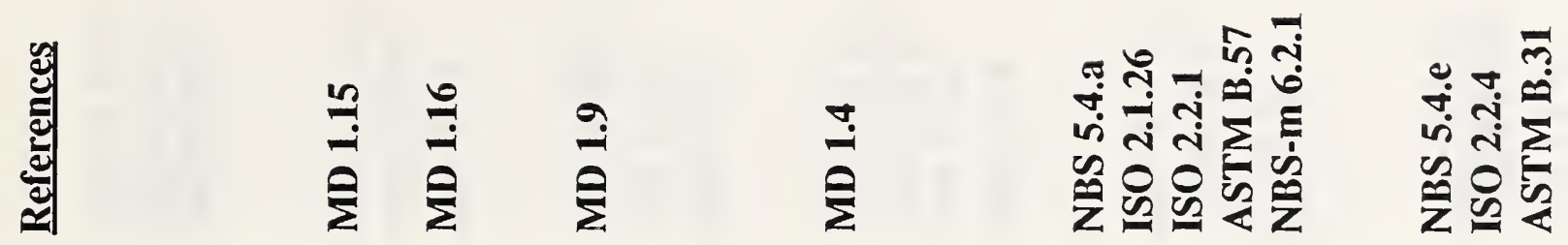

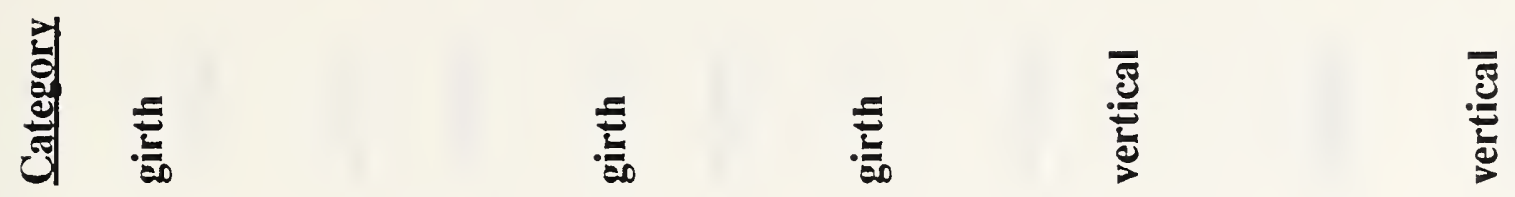

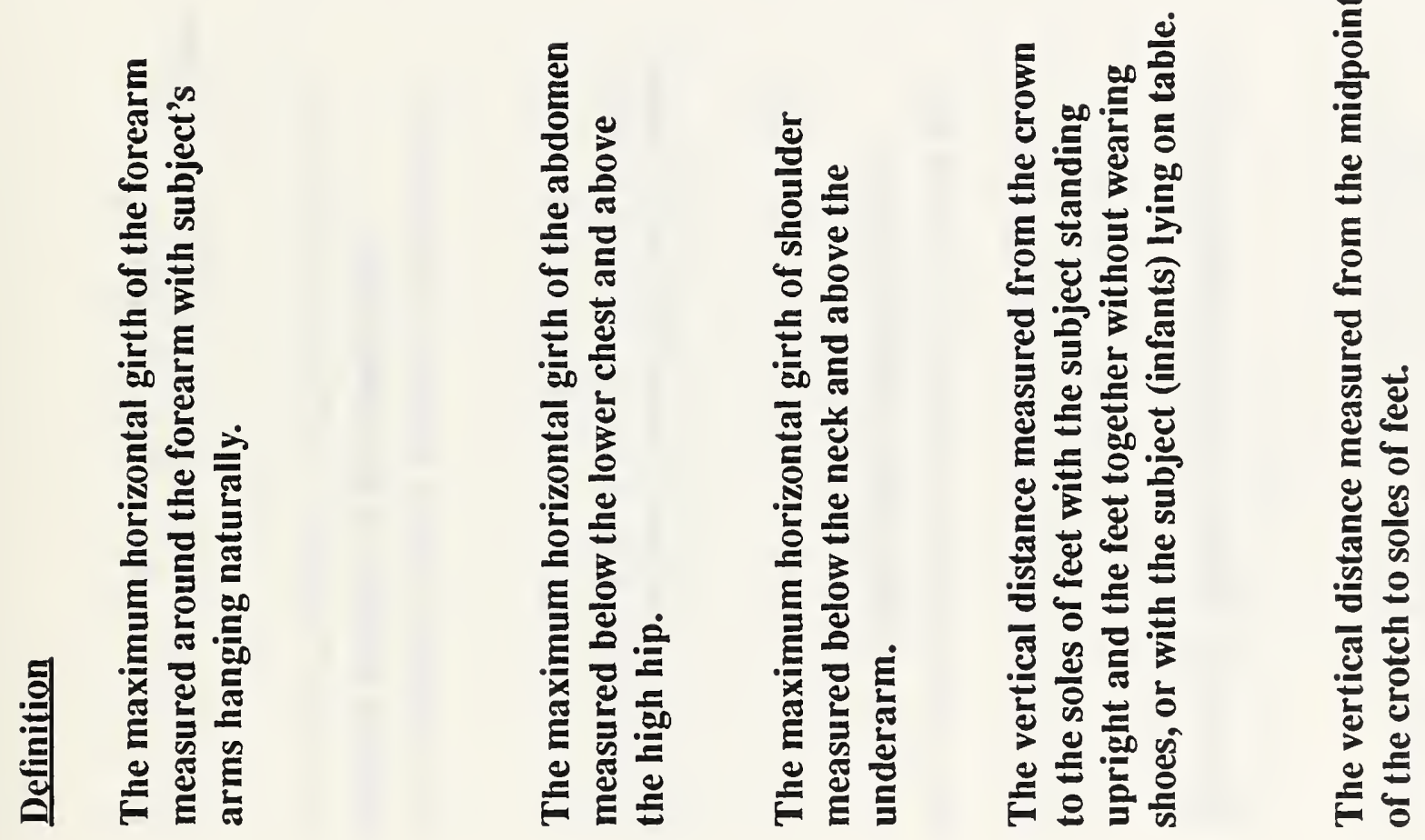

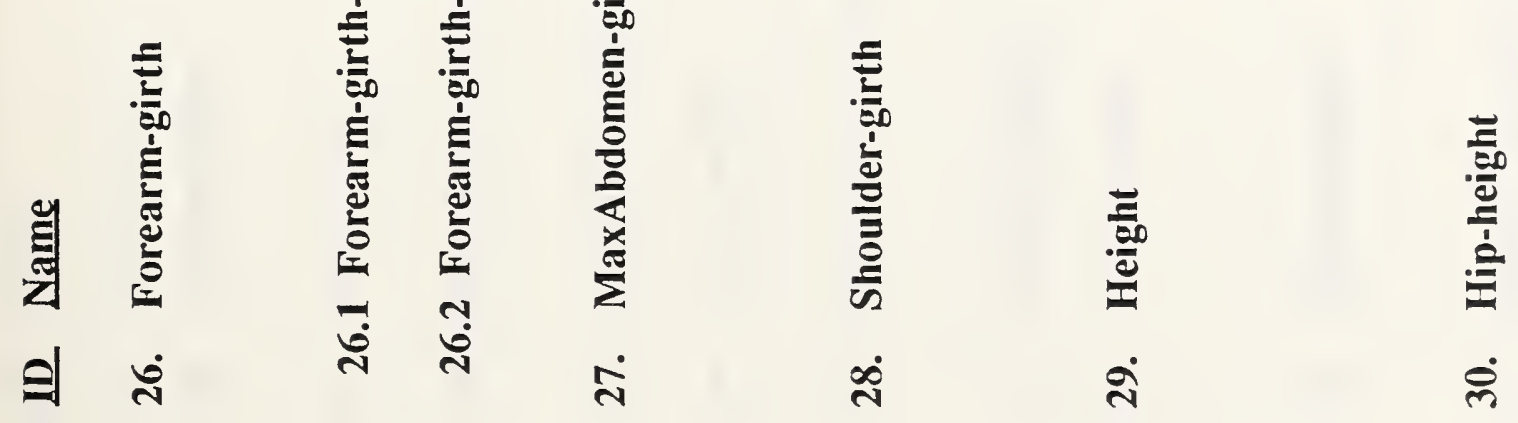




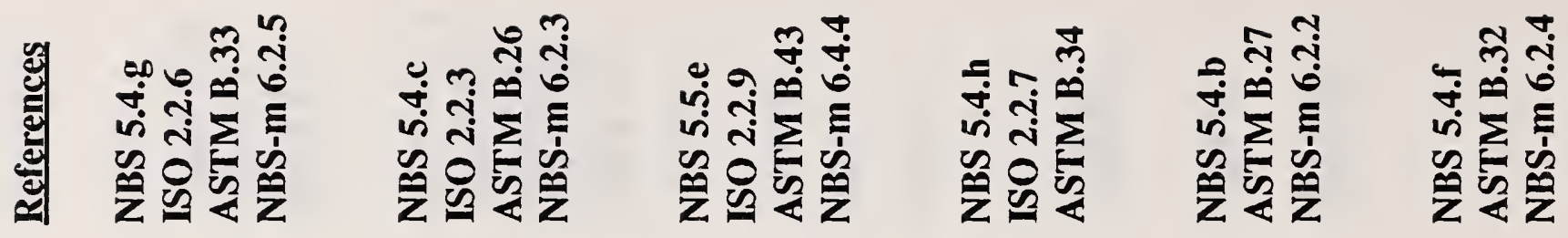
害

害

咅

旁

를

$\frac{\sqrt[3]{0}}{2}$

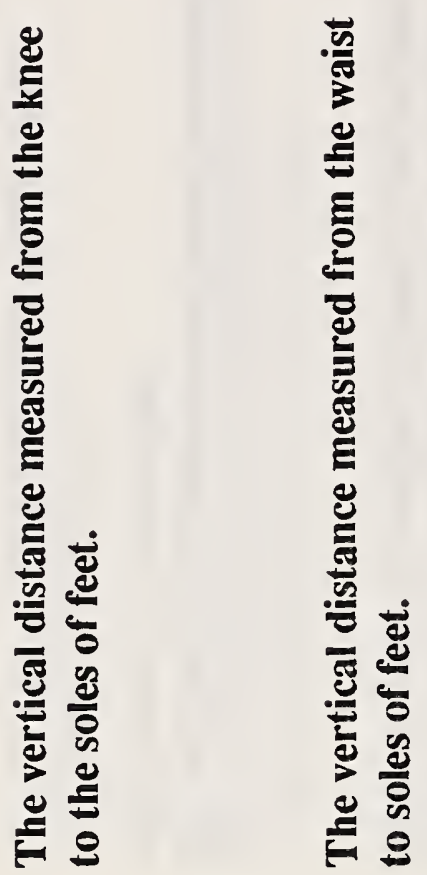

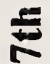

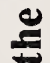

อั

을

氜

ฮี

E

$\stackrel{8}{\varrho}$

존

$\frac{2}{3}$

武

$\stackrel{8}{0}$
툰

$\stackrel{\Xi}{\Xi}$

हี่

8

를

递

논

콜

휼

롱 $\frac{2}{3}$

플

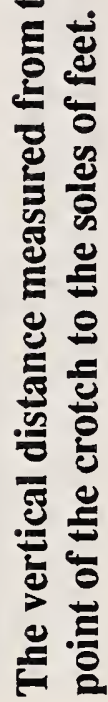

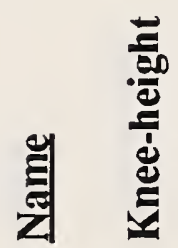

의 ल

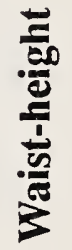

กี

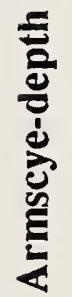

ก่

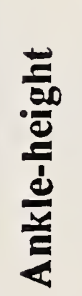

में

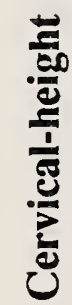

ก่

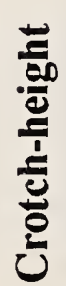

ஸे 
Page 17

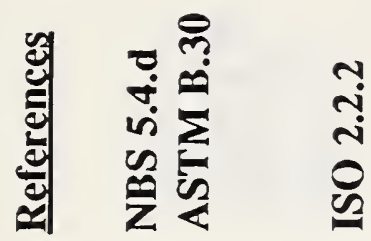

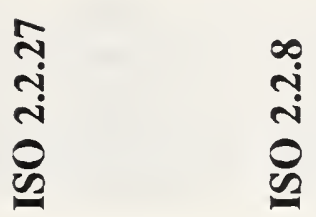

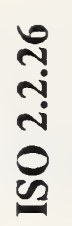

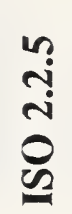

$\sum_{\substack{\infty \\ \vdots}}^{\infty}$

착 률

를

ֻ

:

:

플

$\cong$

롤

巳ัّ

항

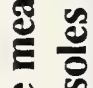

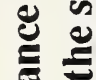

. ํㅗㅇ

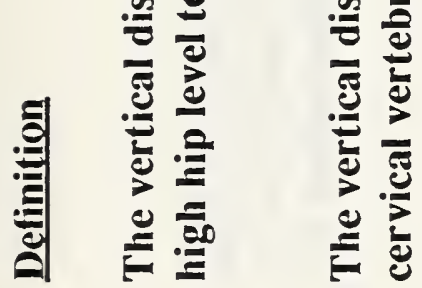

$\equiv$

흘

$\cong$

5.

巳

$\Rightarrow$

ङ

ठै

宽

들

흘

$\stackrel{2}{\varrho}$

을 $\equiv$

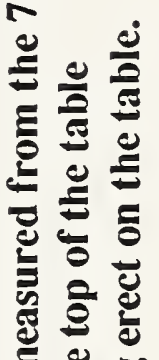

藏.

纯

氙

हु

ํㅡㄹ

焉要言
:

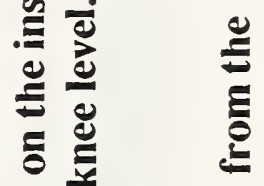

를

홀

ए

造 造

를

홀

政

焉
로을

일

흘

异 $\frac{\bar{n}}{\pi}$

क

气્

छ

폰

है

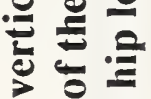

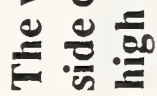

菊离

요

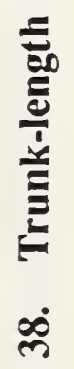

总

ले

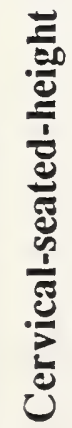

$\dot{q}$

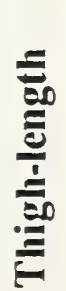

苞

ช
音

ซ 
Page 18

훙

กิ่

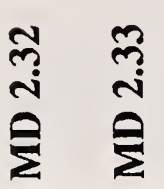

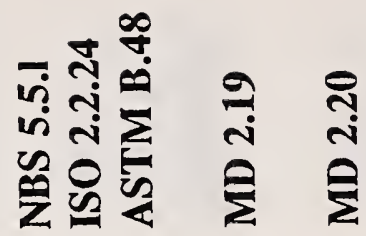

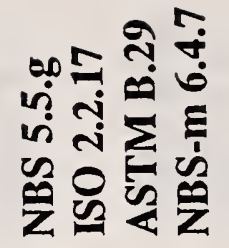

章毫

喜

衰

衰

旁

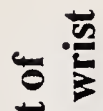

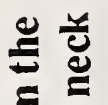

言

늘

을

E

छ

을

흔

론

言

8

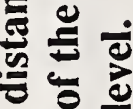

ฮึ

호

을

政

尊密

ह

궁

串

可

$\pm \overline{0}$

¿

훙

宅

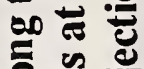

ह

흔

政

这

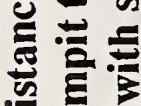

는

芦总产

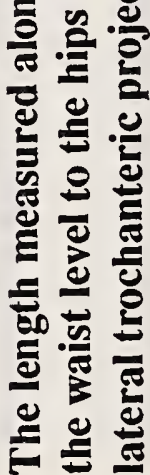

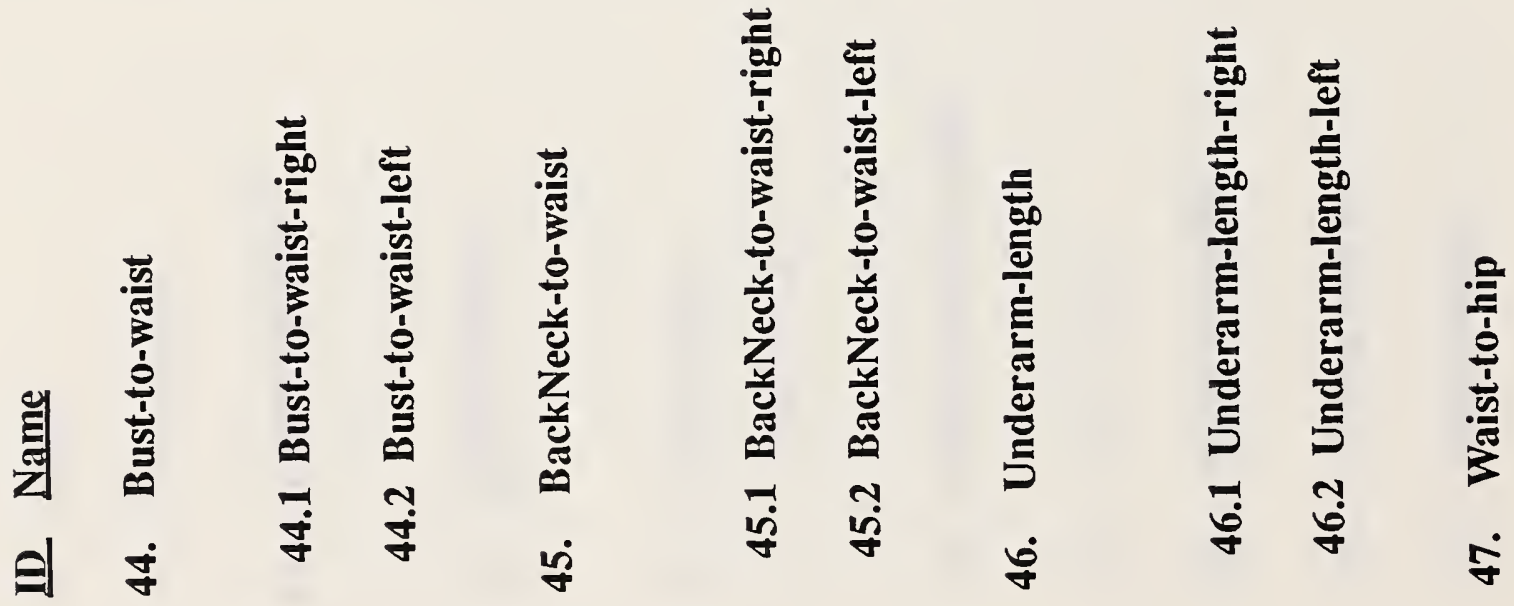




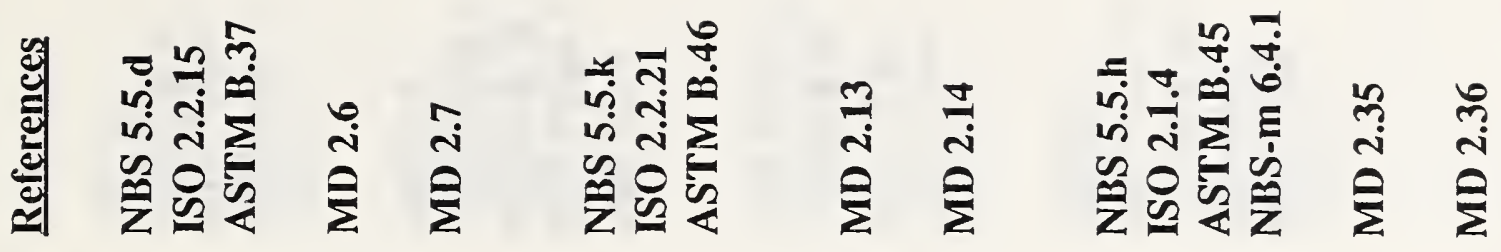

童

言耪

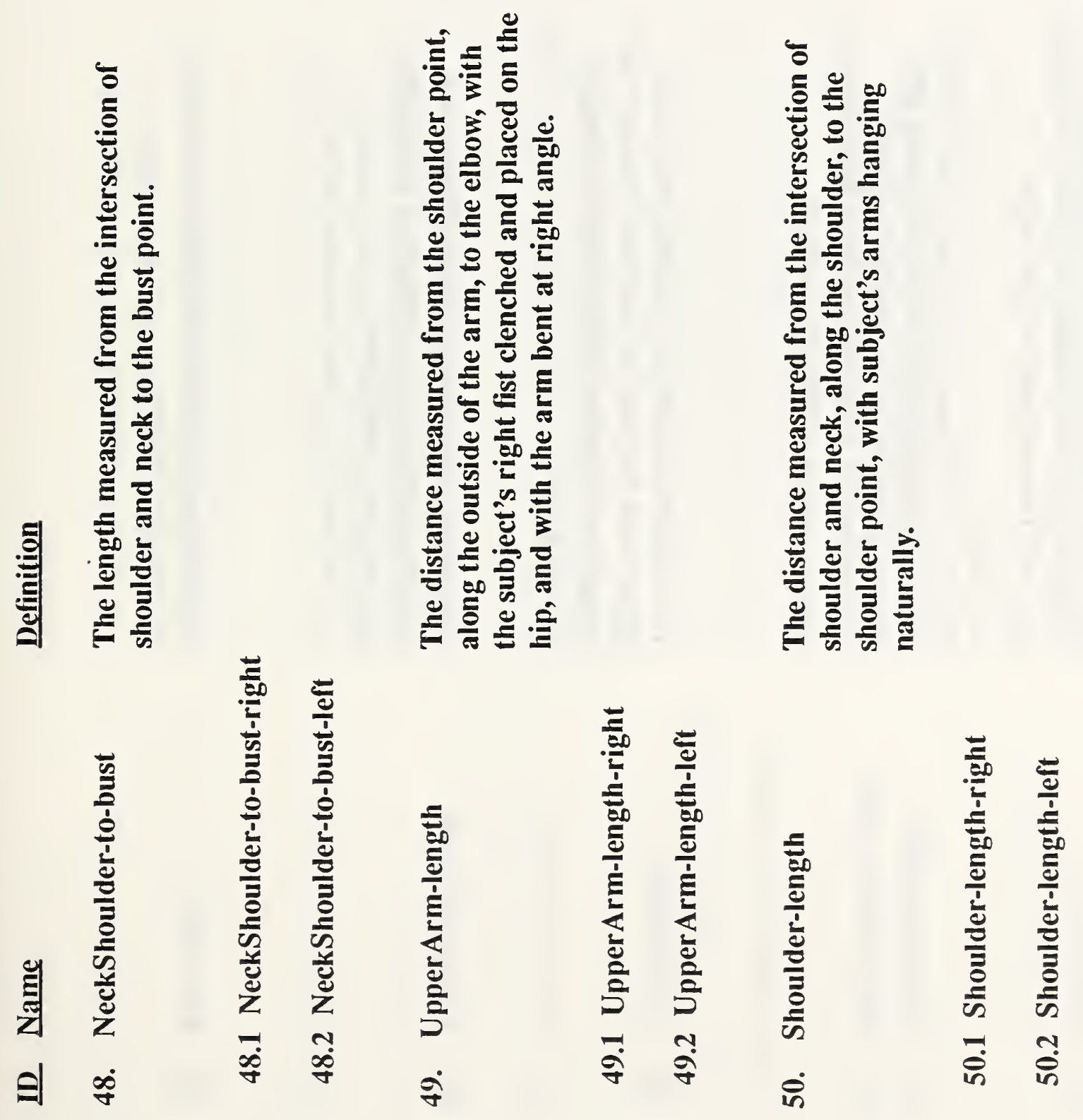



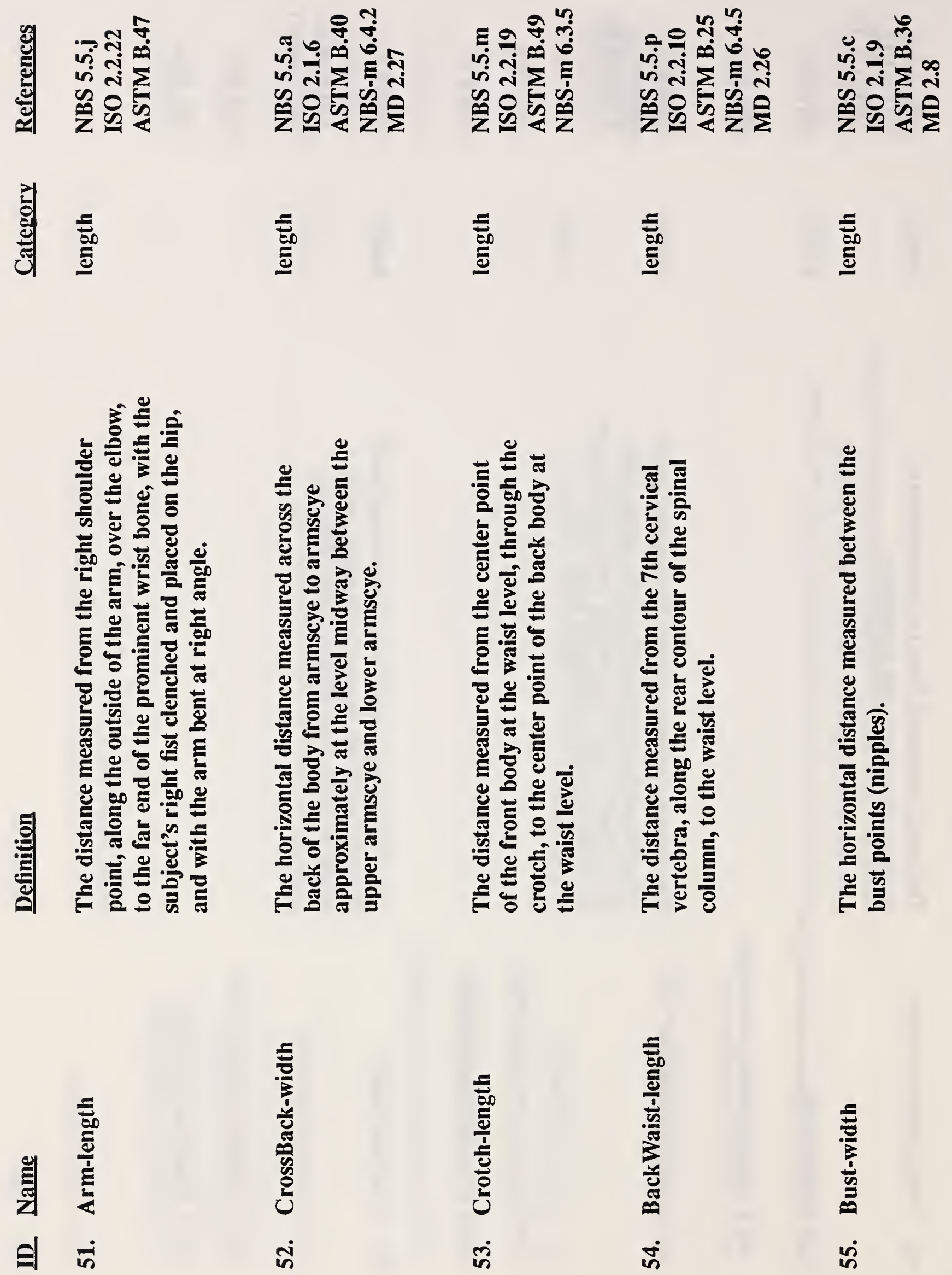


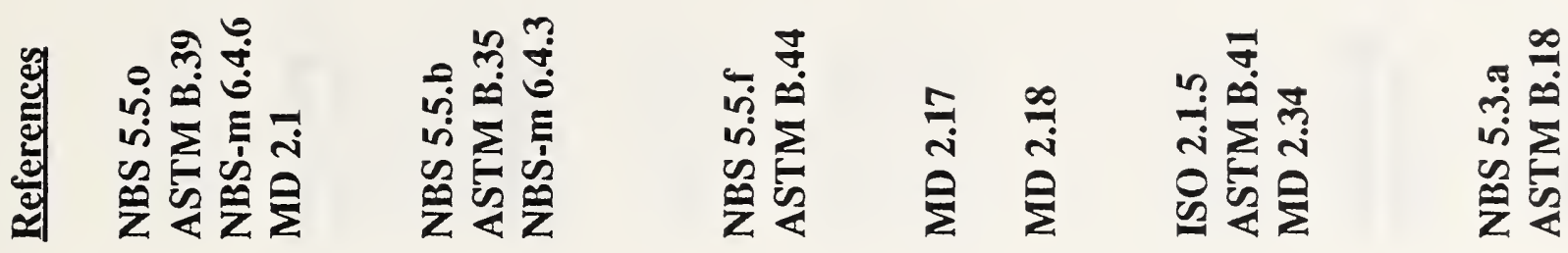

量

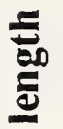

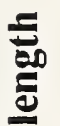

$\underline{\underline{\underline{E}}}$

$\underline{\underline{E}}$

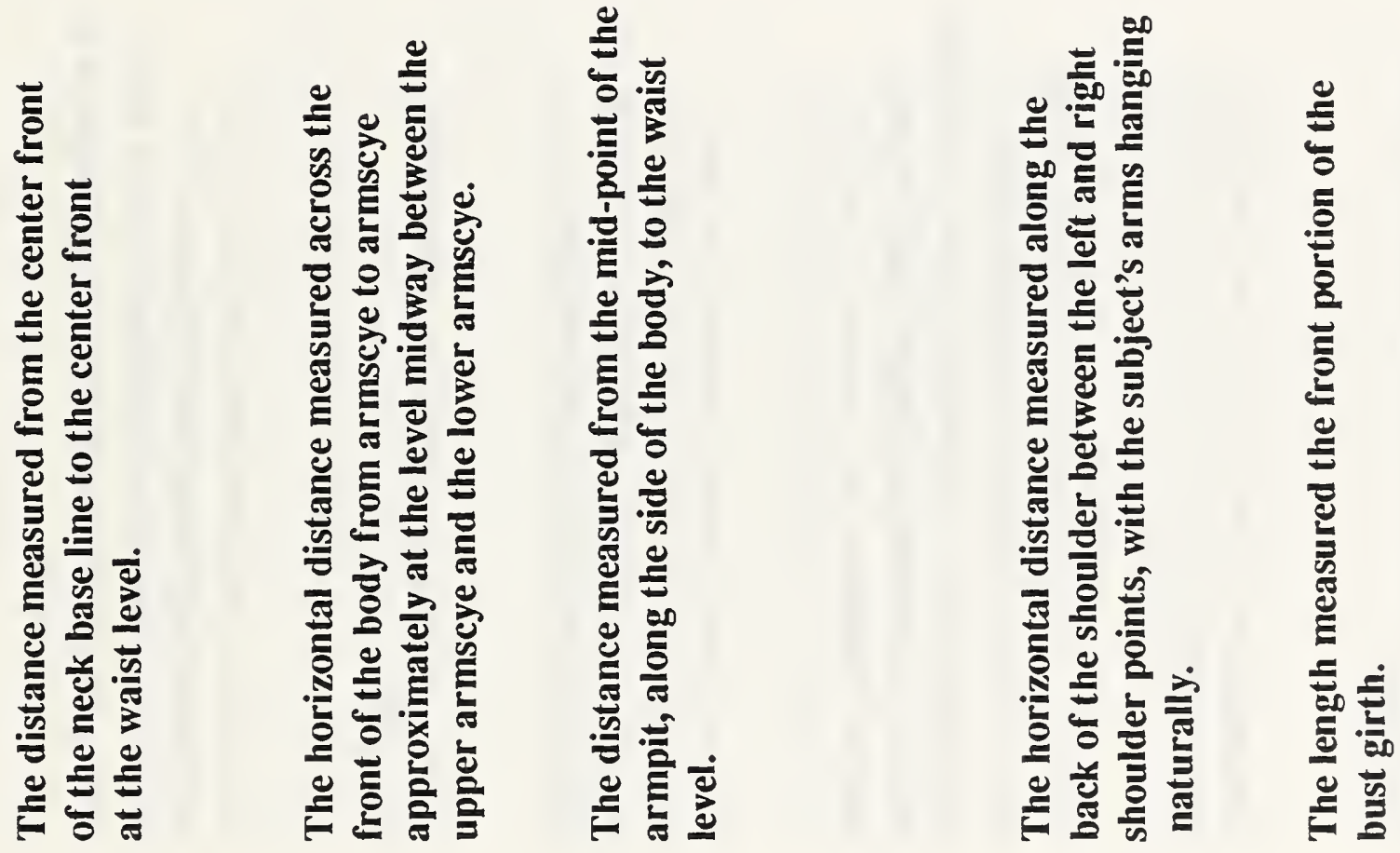

章 氙

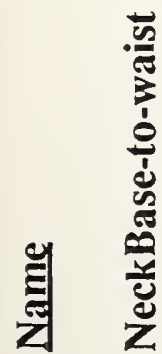

ق

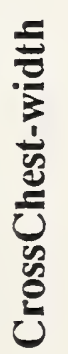

in

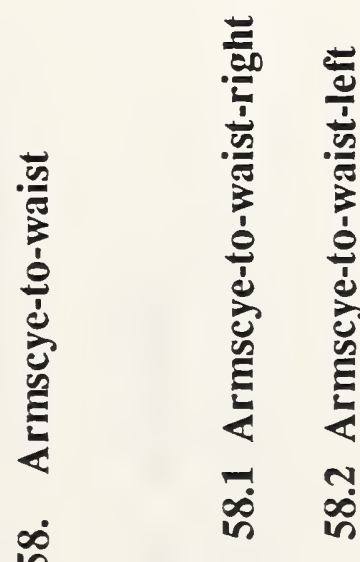

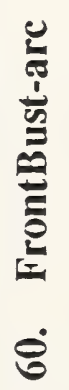


Page 22
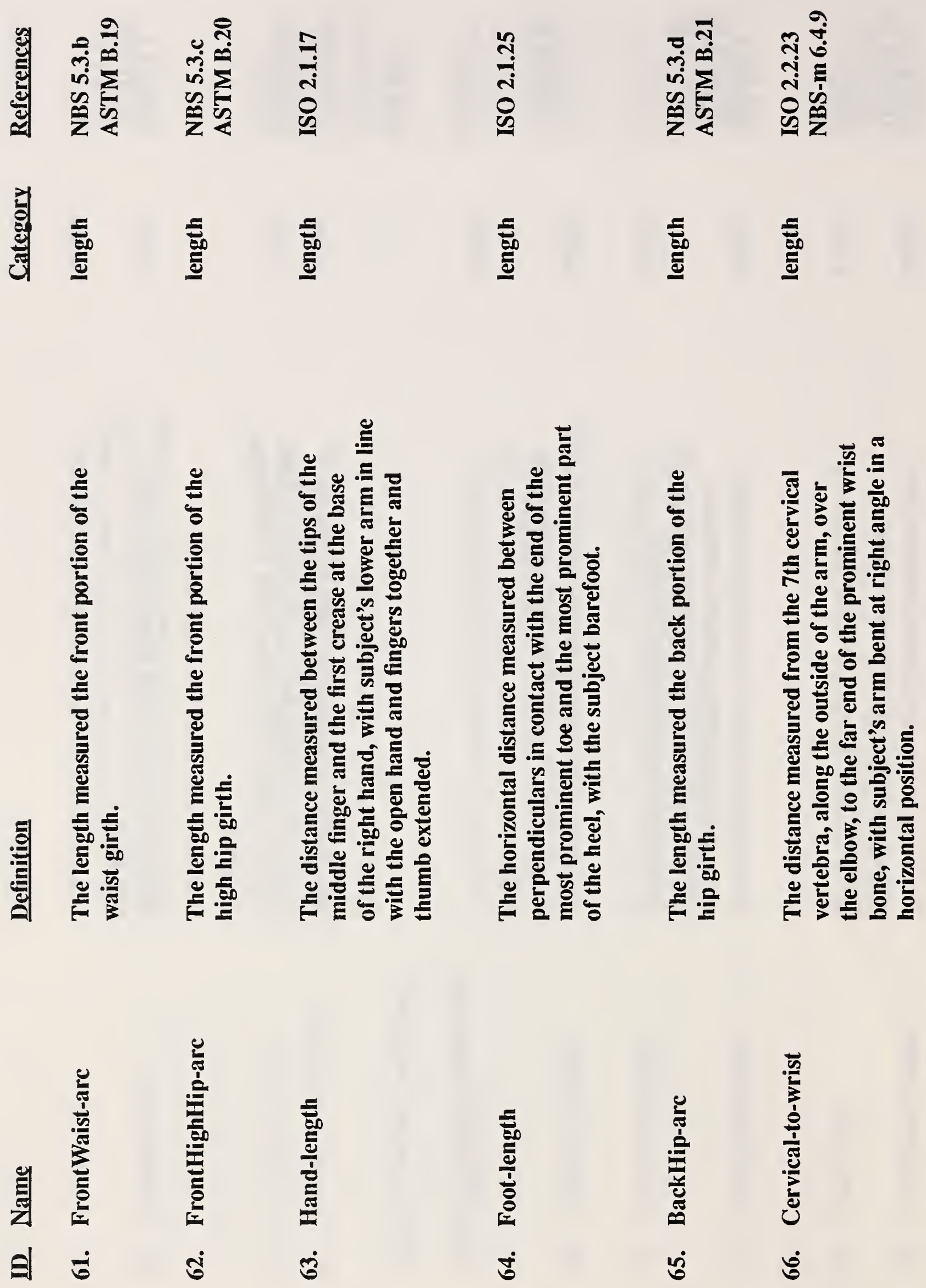
Page 23

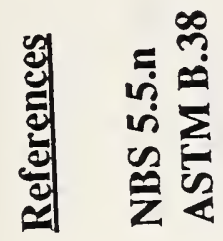

害

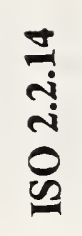

$\stackrel{\overline{\underline{*}}}{\underline{\underline{E}}}$

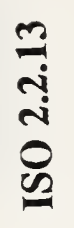

อ

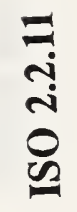

를

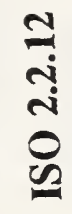

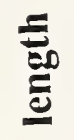

를

E

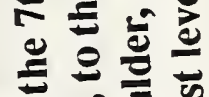

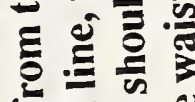

를 总

突导

象

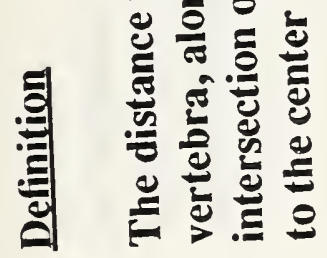

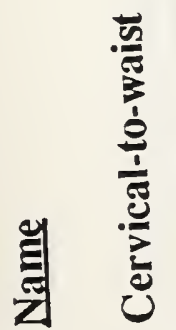

$\Rightarrow \dot{0}$

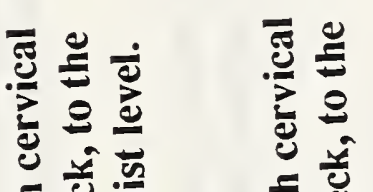

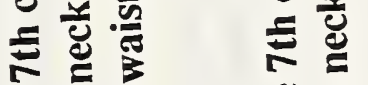

兰兰五 五

등

을

产导突

总訏

噌

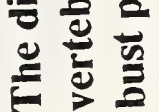

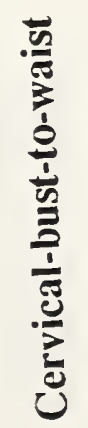

ه্ర

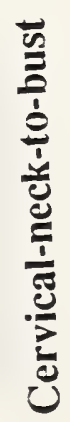

ல்

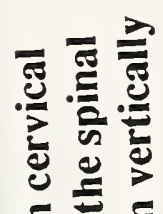

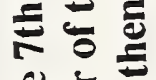

总言郭

政

氙

ङ

혼

於

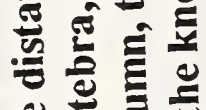

总焉

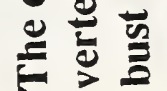

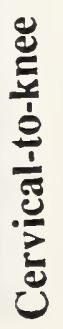

$\stackrel{2}{2}$

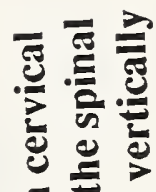

츨

至

ह

类

衰它递

ह

殸

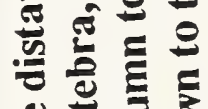

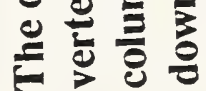

$\frac{\bar{\Xi}}{\frac{0}{0}}$

$\dot{2}$ 
Page 24

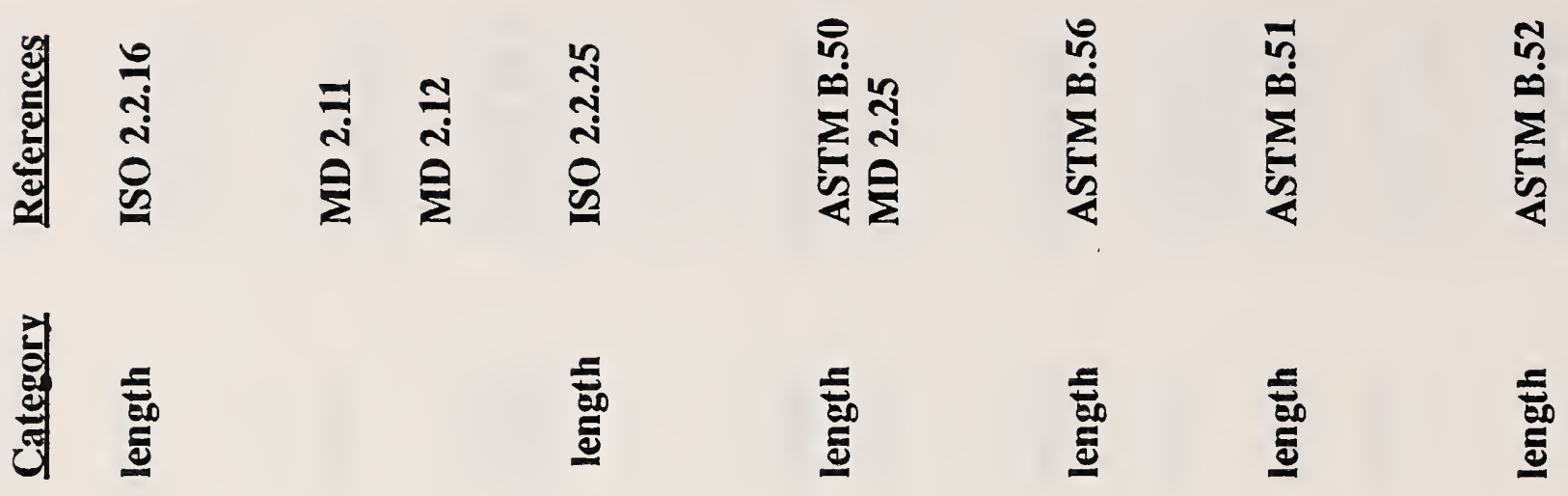
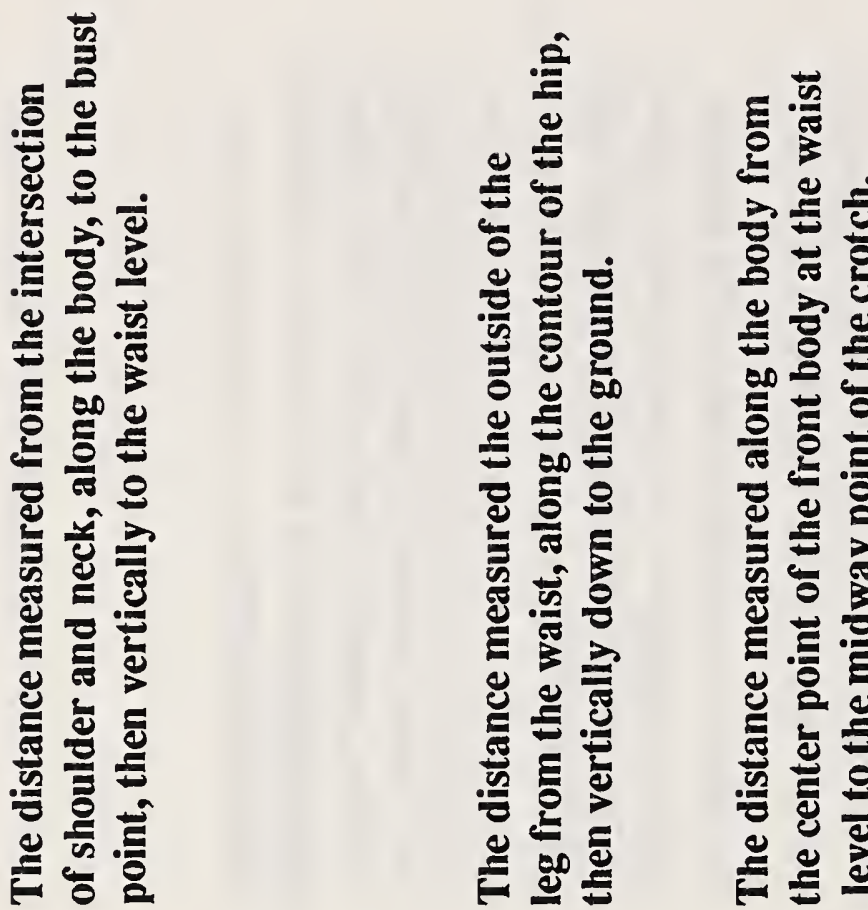

통

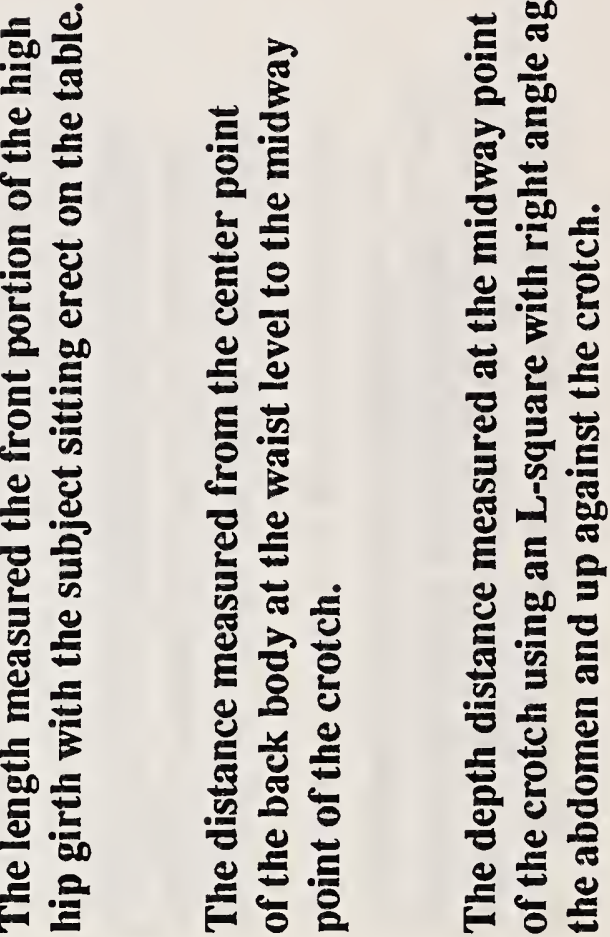

毫毫

$\exists \stackrel{1}{ }$

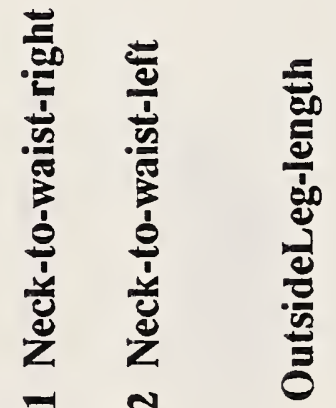

$\overline{\text { i }}$

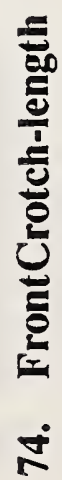

in
İ

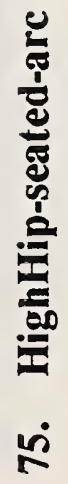

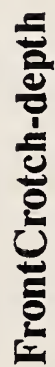

i 

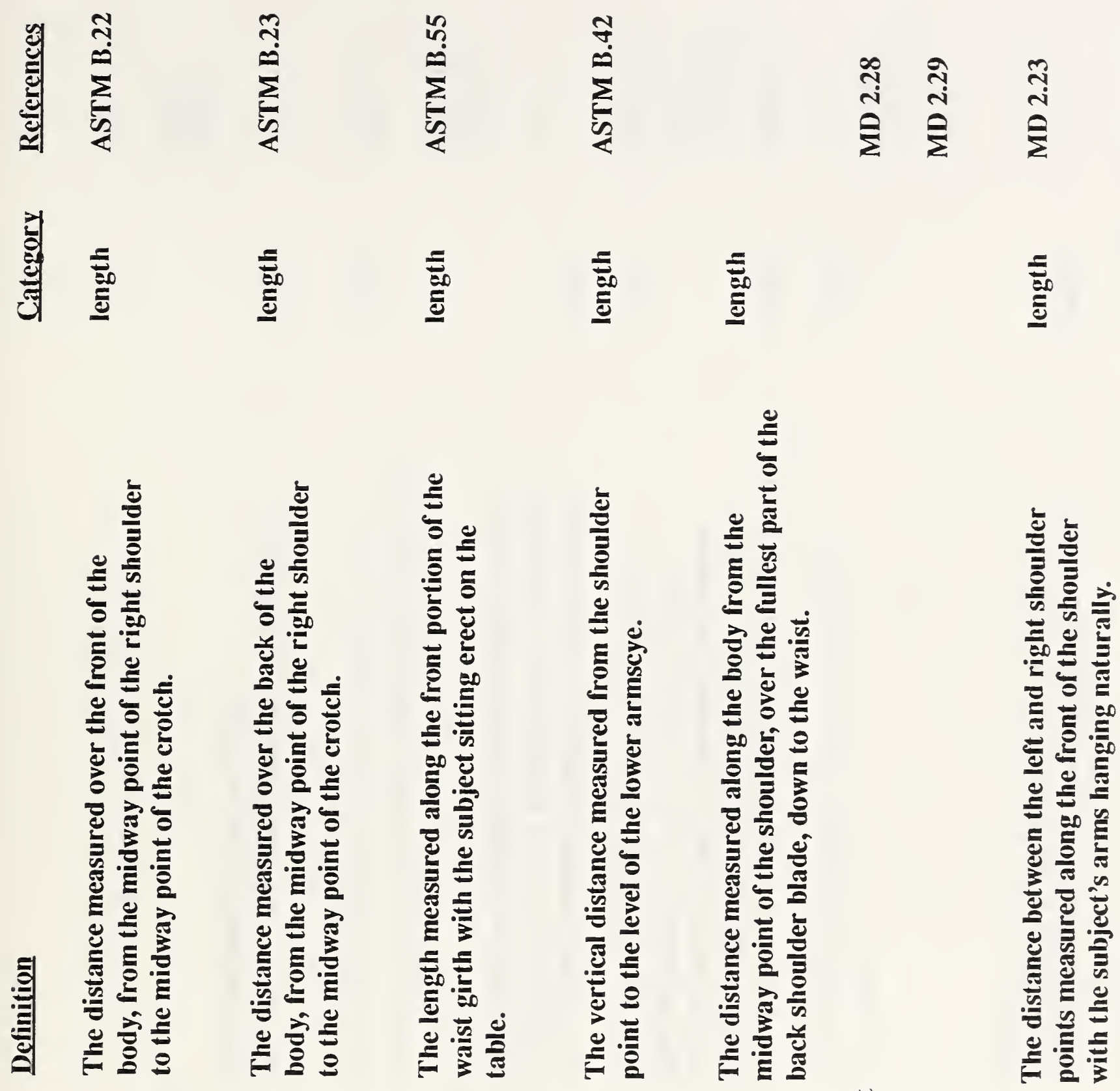

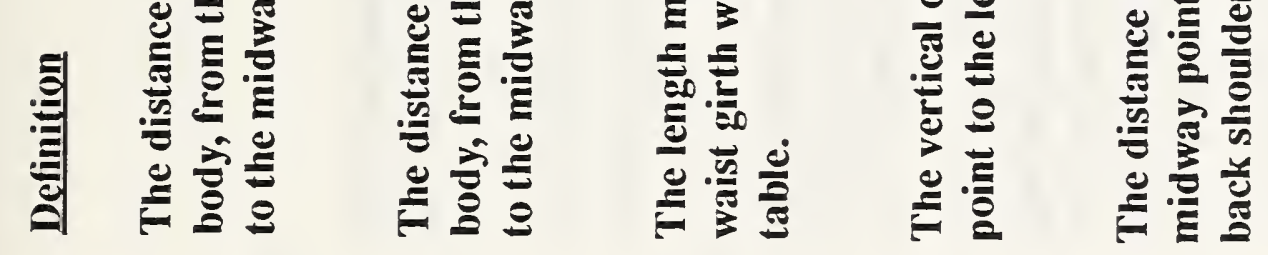

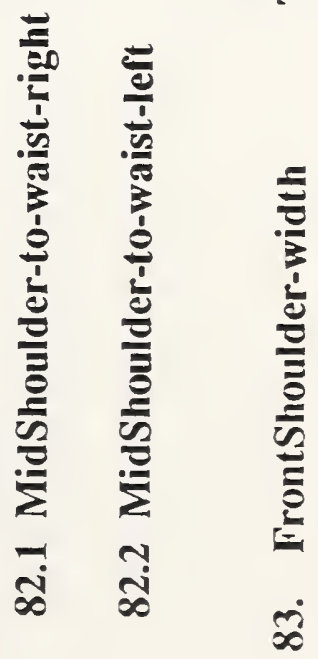




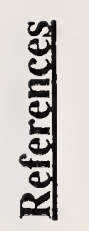

商草

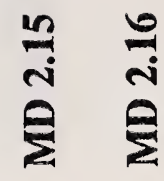

กิ

基

高

衰

裹

을

를

『

. छิ

(5)

을

E

政

焉

政

8

青雚

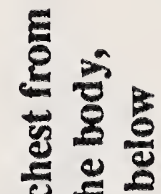

言范

은

要

政

을

案

政

क्ष क्ष

월 ह

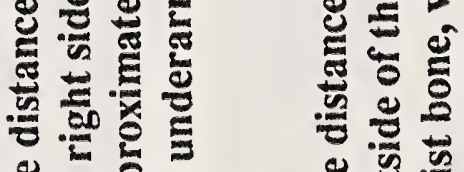

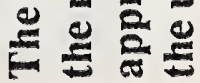

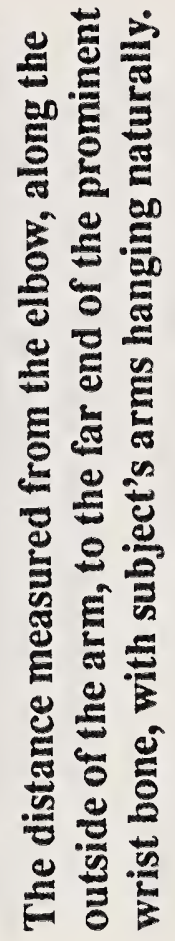

送

.

흘

竞

空

.

을

㮫

曾

跣
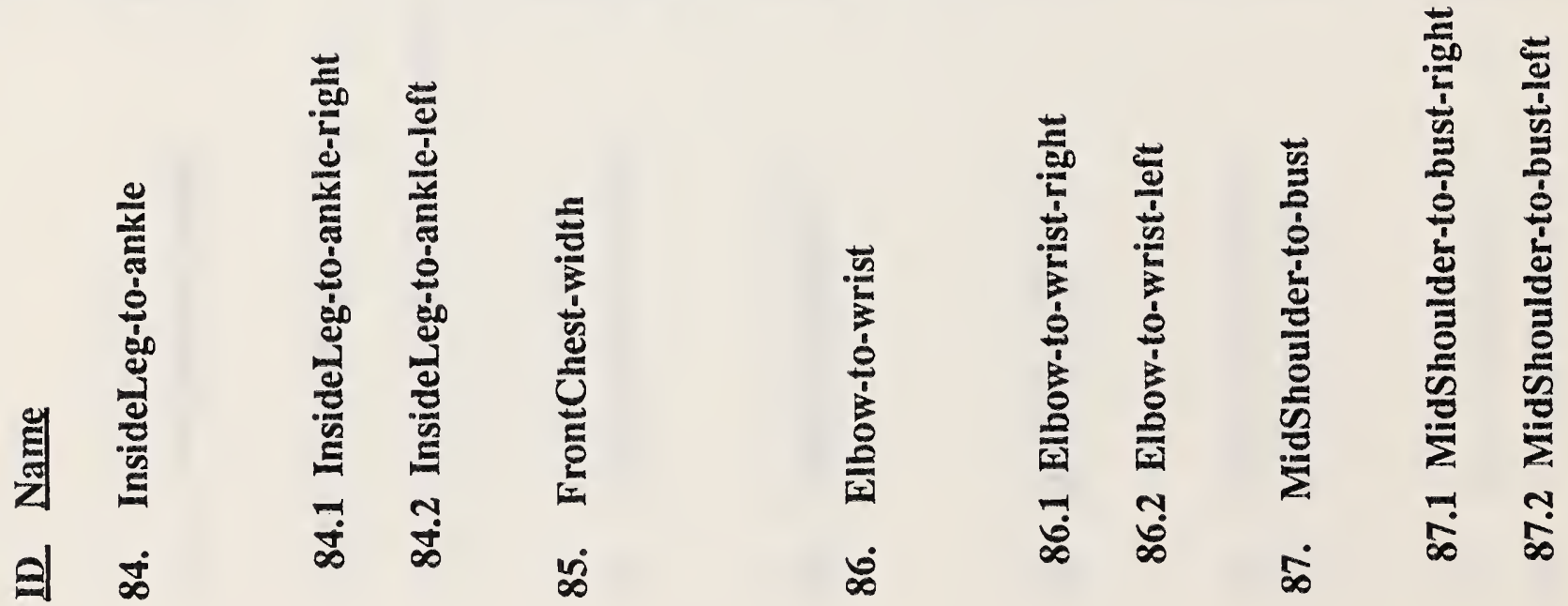
Page 27

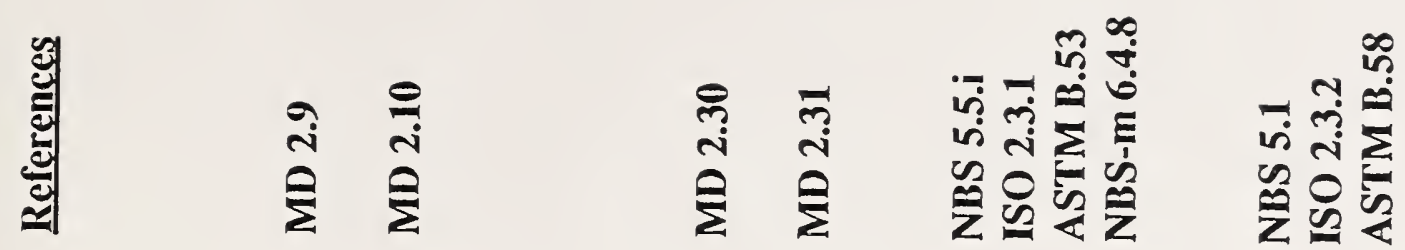

意咅

部

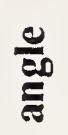

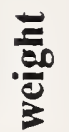
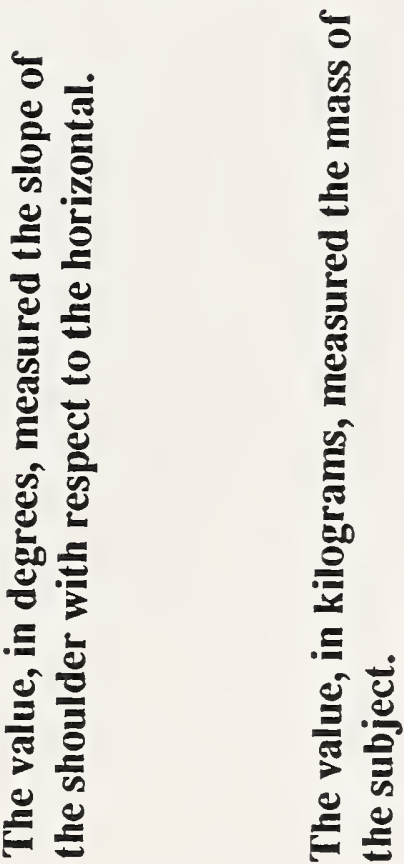

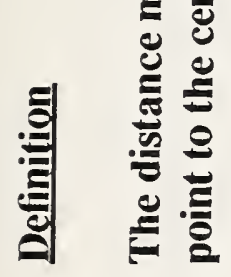
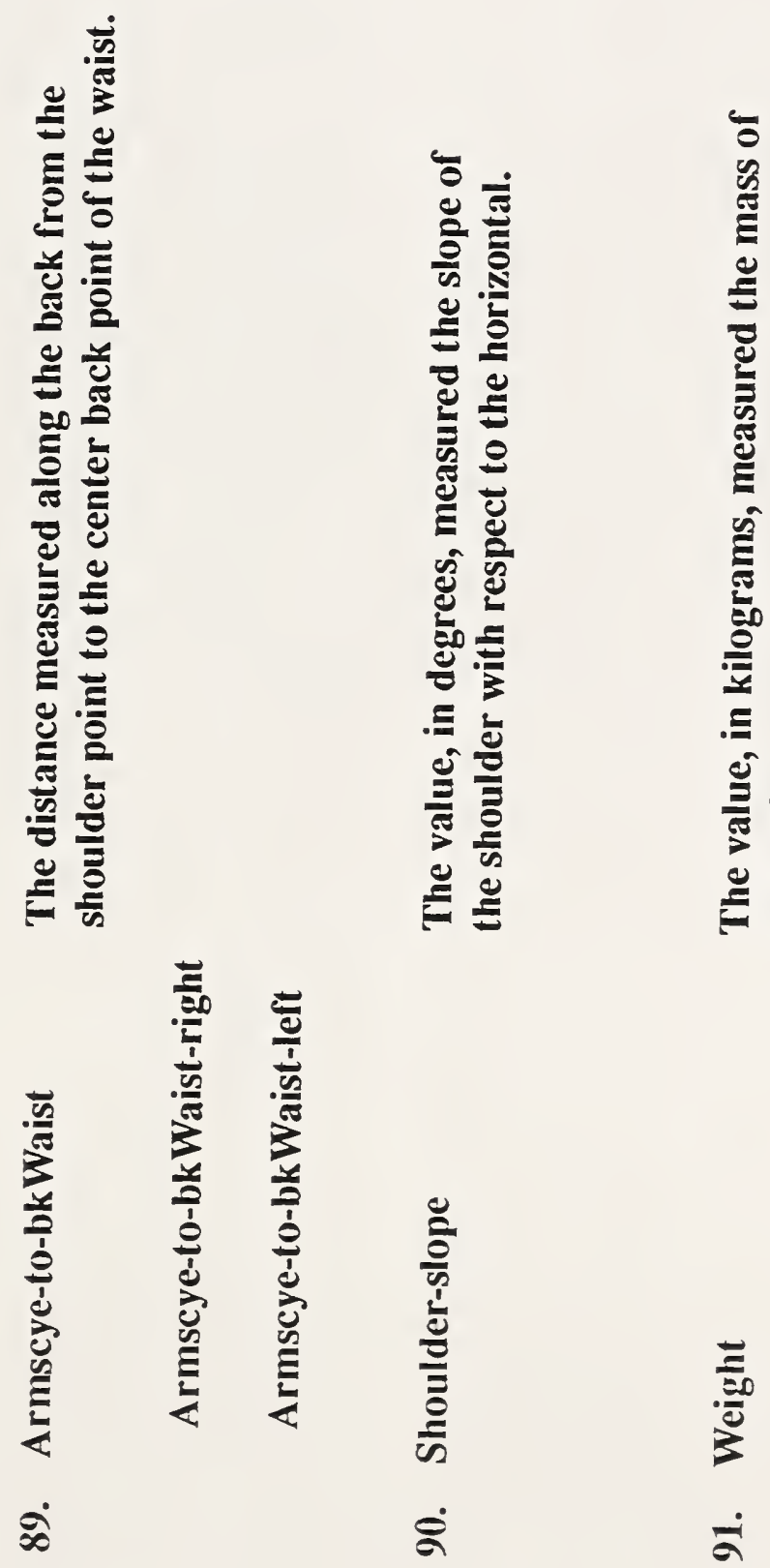

$\frac{E}{3}$

$\exists \dot{\infty} \infty \begin{array}{cc}\infty & \infty \\ \infty & \dot{\infty}\end{array}$ 


